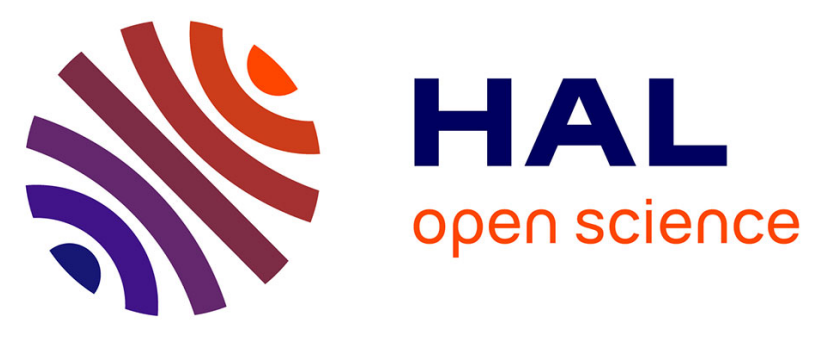

\title{
Humoral Immune Responses to Epstein-Barr virus encoded Tumor Associated Proteins and their Putative Extracellular Domains in Nasopharyngeal Carcinoma Patients and Regional Controls
}

Dewi Kartikawati Paramita, Christien Fatmawati, Hedy Juwana, Frank G. van Schaijk, Jajah Fachiroh, Sophia Mubarika Haryana, Jaap M. Middeldorp

\section{To cite this version:}

Dewi Kartikawati Paramita, Christien Fatmawati, Hedy Juwana, Frank G. van Schaijk, Jajah Fachiroh, et al.. Humoral Immune Responses to Epstein-Barr virus encoded Tumor Associated Proteins and their Putative Extracellular Domains in Nasopharyngeal Carcinoma Patients and Regional Controls. Journal of Medical Virology, 2011, 83 (4), pp.665. 10.1002/jmv.21960 . hal-00614671

\section{HAL Id: hal-00614671 \\ https://hal.science/hal-00614671}

Submitted on 15 Aug 2011

HAL is a multi-disciplinary open access archive for the deposit and dissemination of scientific research documents, whether they are published or not. The documents may come from teaching and research institutions in France or abroad, or from public or private research centers.
L'archive ouverte pluridisciplinaire HAL, est destinée au dépôt et à la diffusion de documents scientifiques de niveau recherche, publiés ou non, émanant des établissements d'enseignement et de recherche français ou étrangers, des laboratoires publics ou privés. 


\section{Humoral Immune Responses to Epstein-Barr virus encoded Tumor Associated Proteins and their Putative Extracellular Domains in Nasopharyngeal Carcinoma Patients and Regional Controls}

\begin{tabular}{|c|c|}
\hline Journal: & Journal of Medical Virology \\
\hline Manuscript ID: & JMV-10-1857.R1 \\
\hline Wiley - Manuscript type: & Research Article \\
\hline $\begin{array}{r}\text { Date Submitted by the } \\
\text { Author: }\end{array}$ & 23-Aug-2010 \\
\hline Complete List of Authors: & $\begin{array}{l}\text { Paramita, Dewi; Gadjah Mada University, Faculty of Medicine } \\
\text { Fatmawati, Christien; Gadjah Mada University, Faculty of Medicine } \\
\text { Juwana, Hedy; VU University medical center, Pathology } \\
\text { van Schaijk, Frank; VU University medical center, Pathology } \\
\text { Fachiroh, Jajah; Gadjah Mada University, Faculty of Medicine } \\
\text { Haryana, Sophia; Gadjah Mada University, Faculty of Medicine } \\
\text { Middeldorp, Jaap; Vrije Universiteit Medical Center, Department of } \\
\text { Pathology }\end{array}$ \\
\hline Keywords: & $\begin{array}{l}\text { Epstein-Barr virus, tumor antigens, humoral immunity, } \\
\text { immunisation, extracellular domains }\end{array}$ \\
\hline
\end{tabular}

\section{SCHOLARONE ${ }^{m}$ Manuscripts}




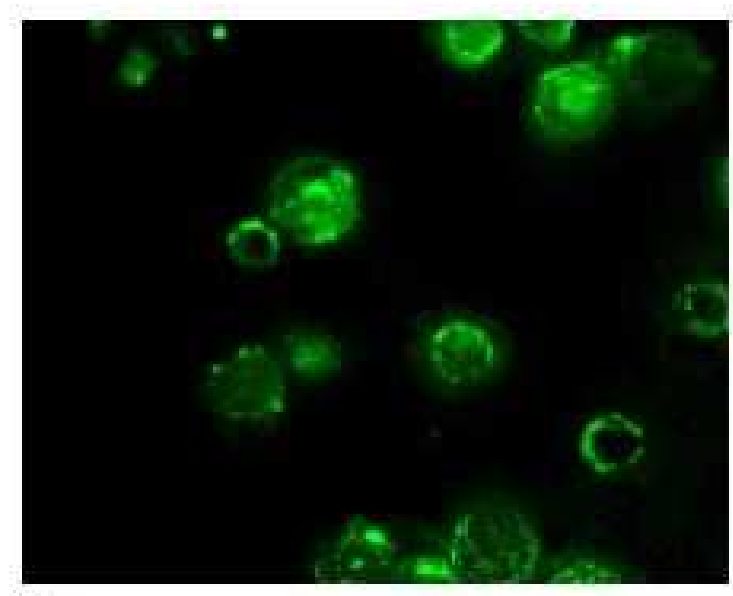

A SF9-EBNA1 OT1X

(1:200)

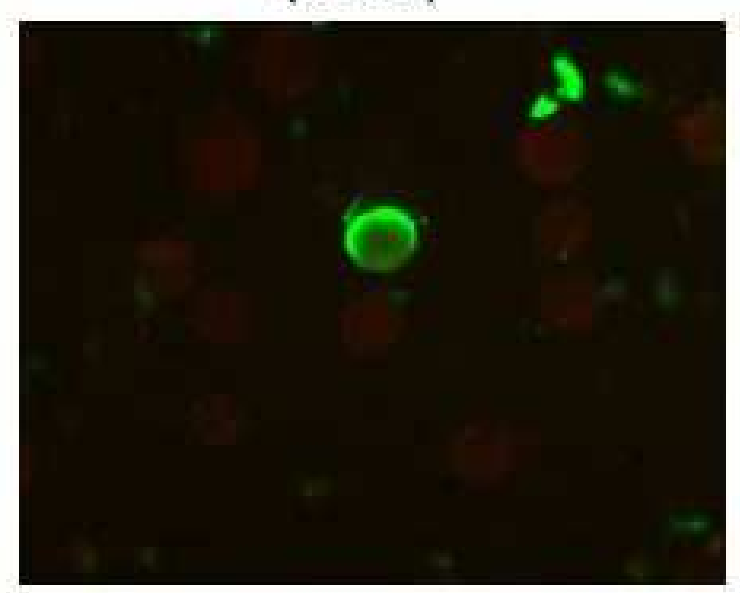

B

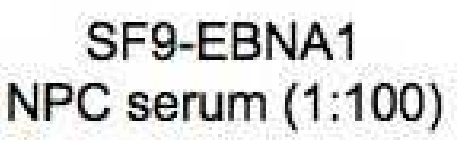

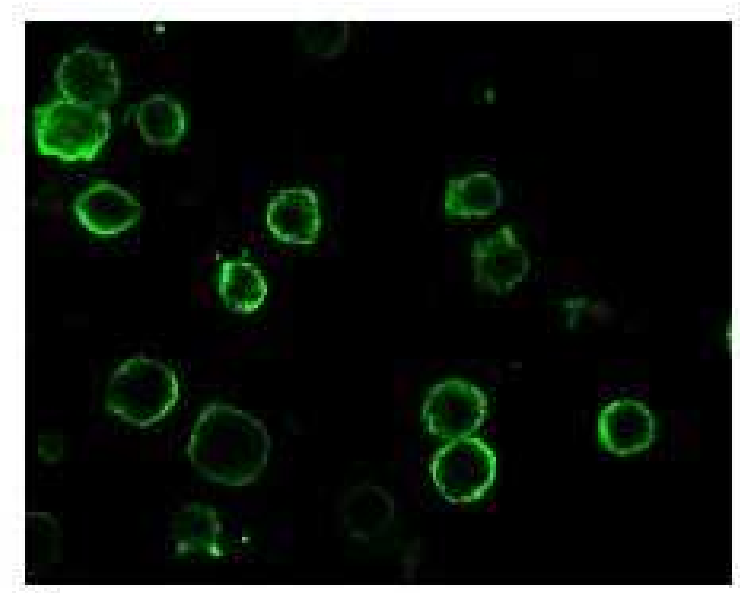

C SF9-LMP1 OT21C

$(1: 00)$

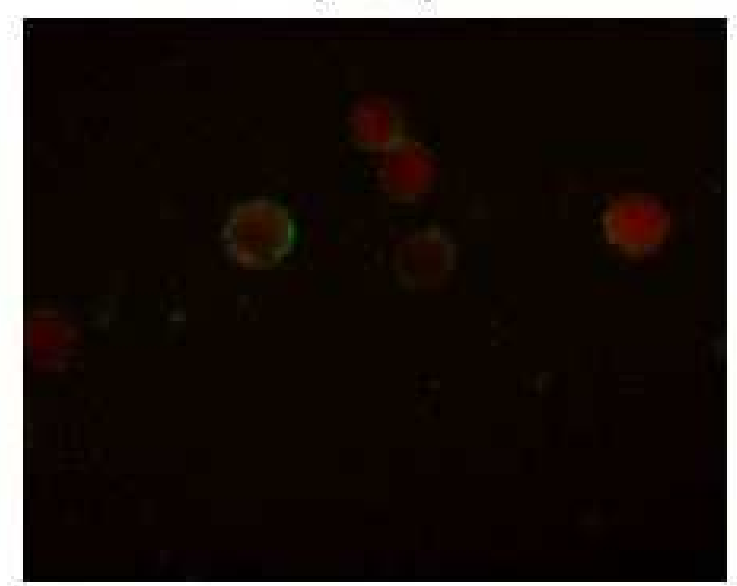

D SF9-LMP1 NPC serum (1:100) F SF9-LMP2 NPC serum $(1: 100)$

Figure 1 


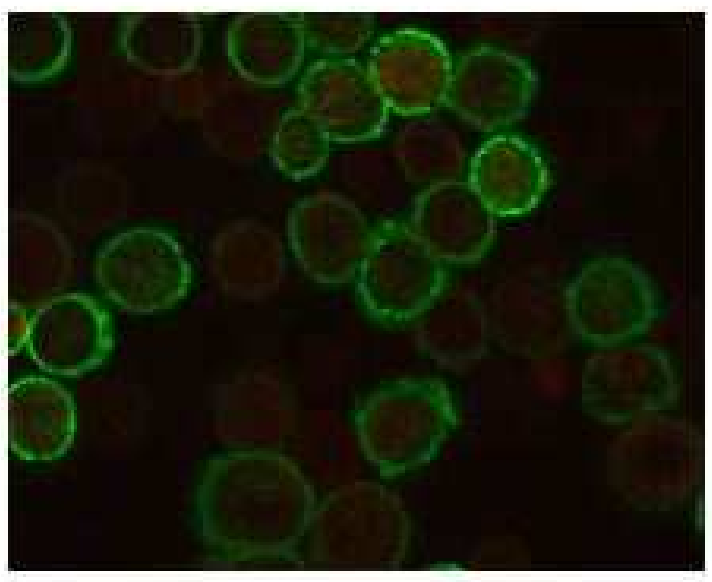

G

SF9-BARF1

K150/4A6 (1:10)

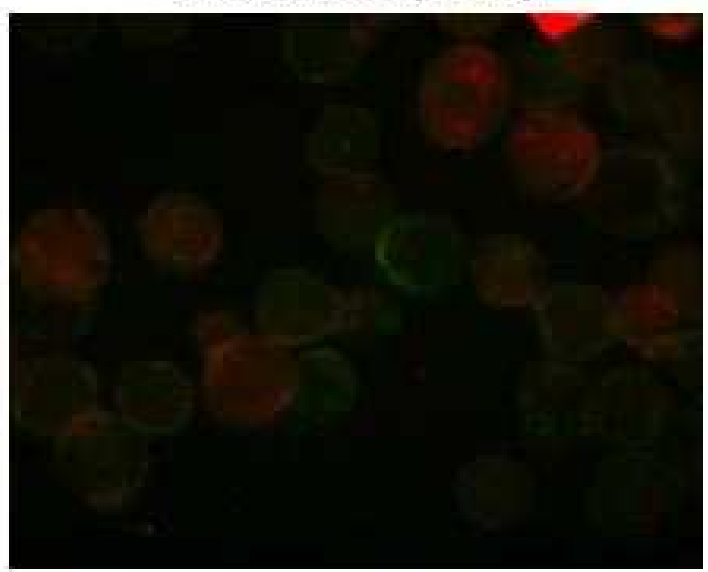

$\mathrm{H}$

SF9-BARF1

NPC serum (1:200)

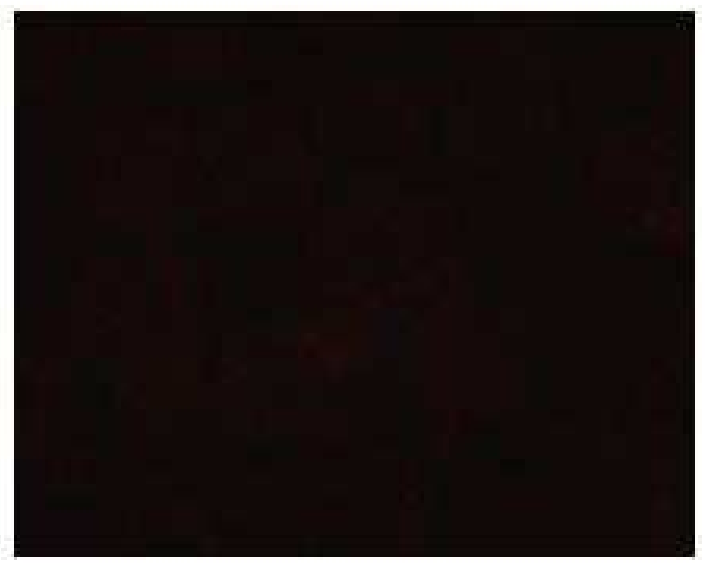

WT-Bac

Figure 1 

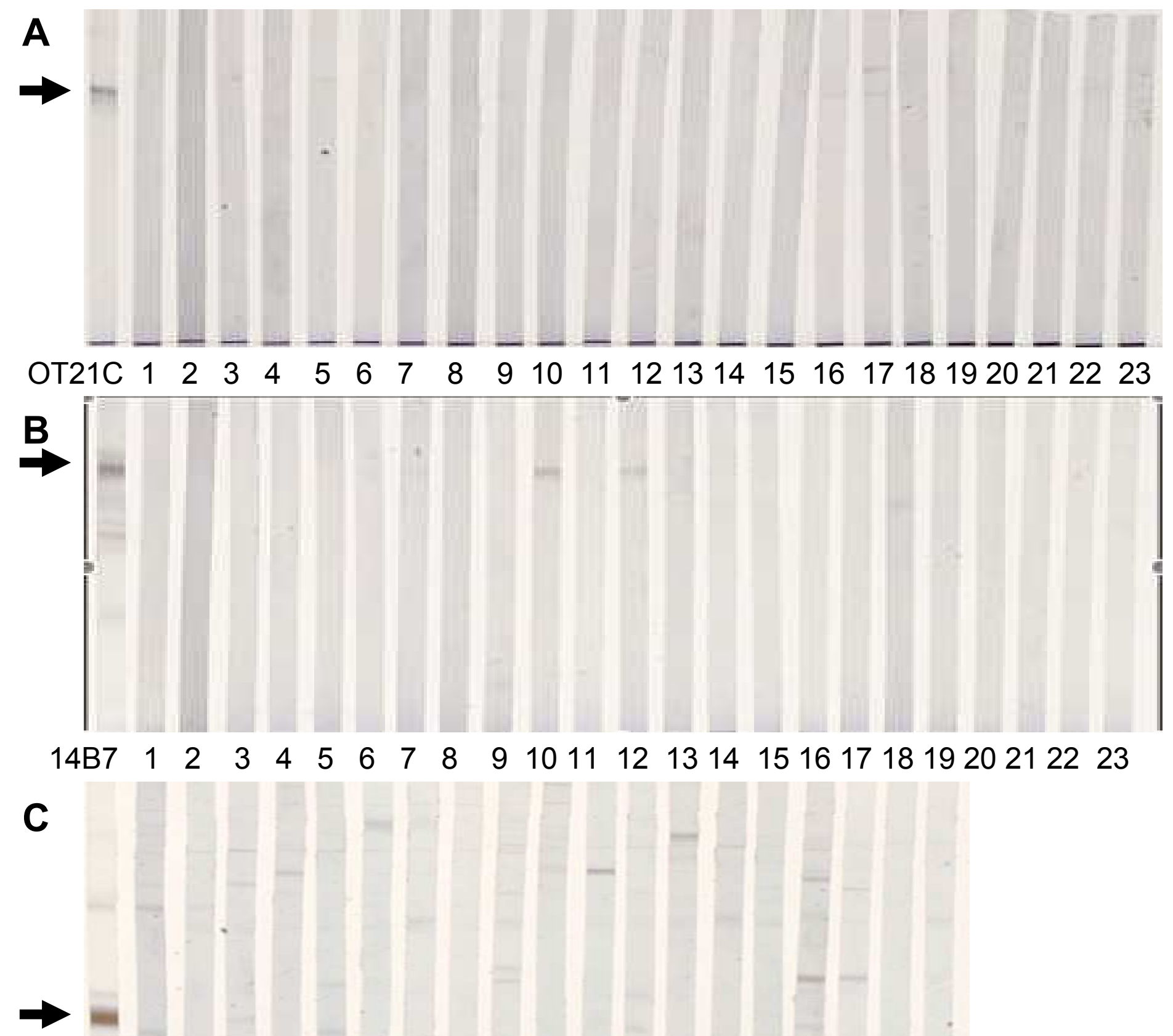

Figure 2 part 1 
D

Antibody Responses in NPC patients to Tumor Associated

Proteins using Immunoblot assay

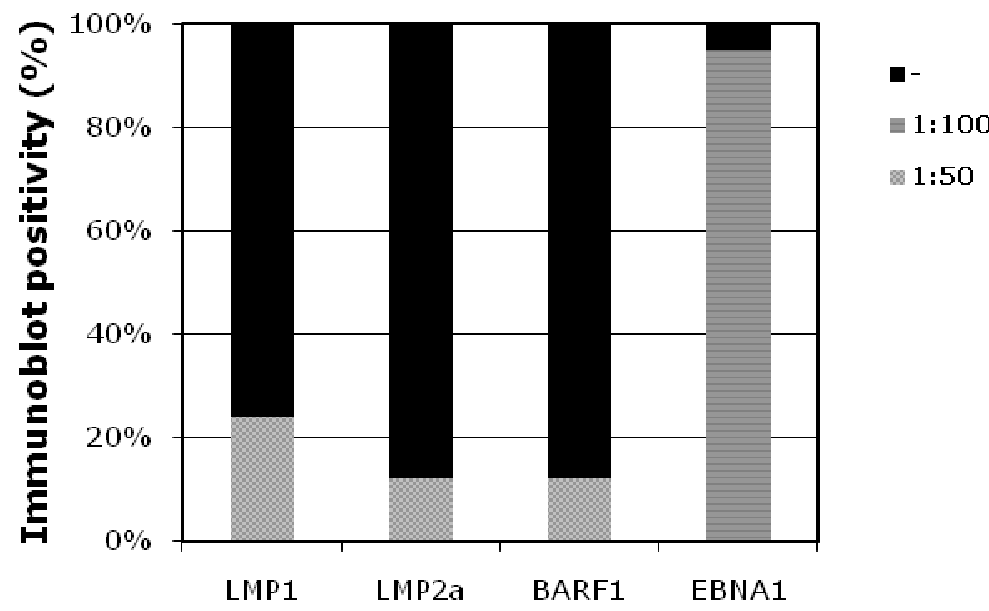

Figure 2 part 2 


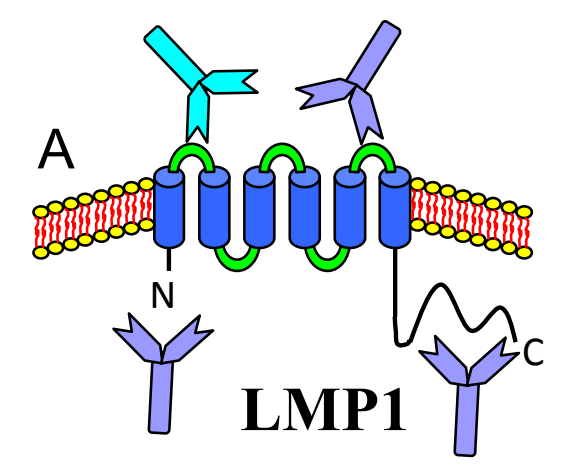

IgG Response to LMP1
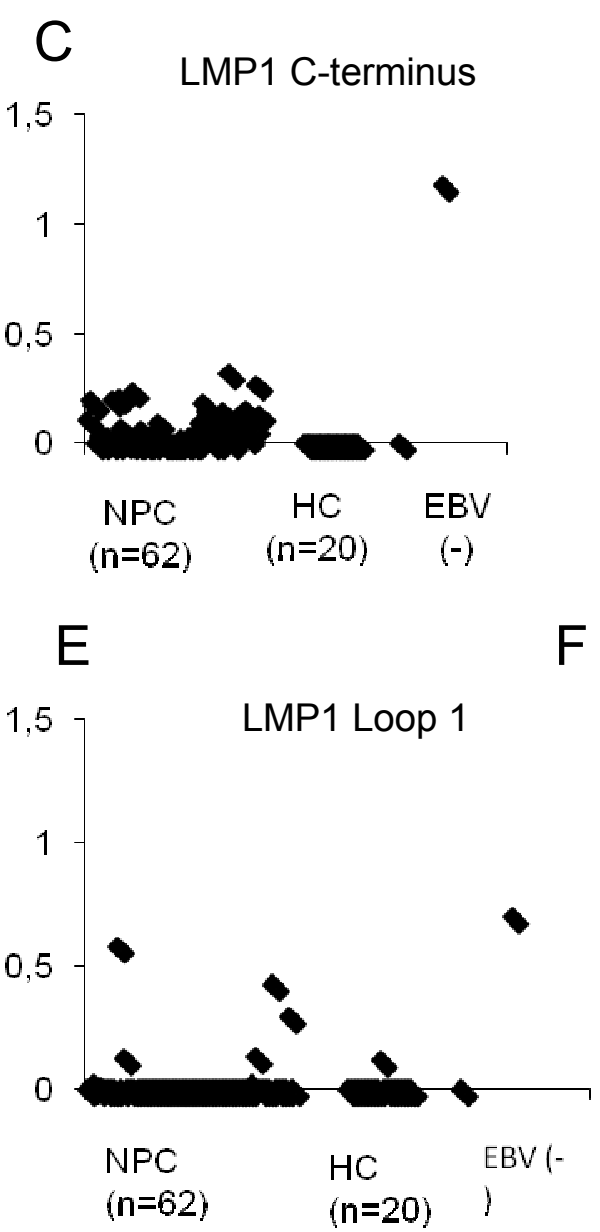

B

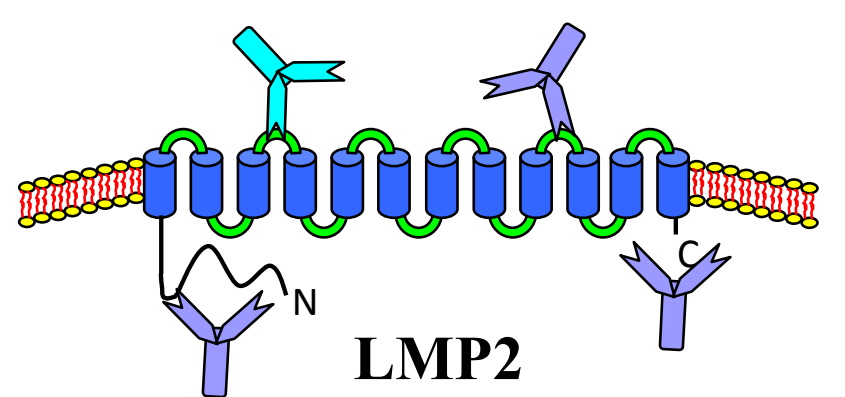

IgG Response to LMP2
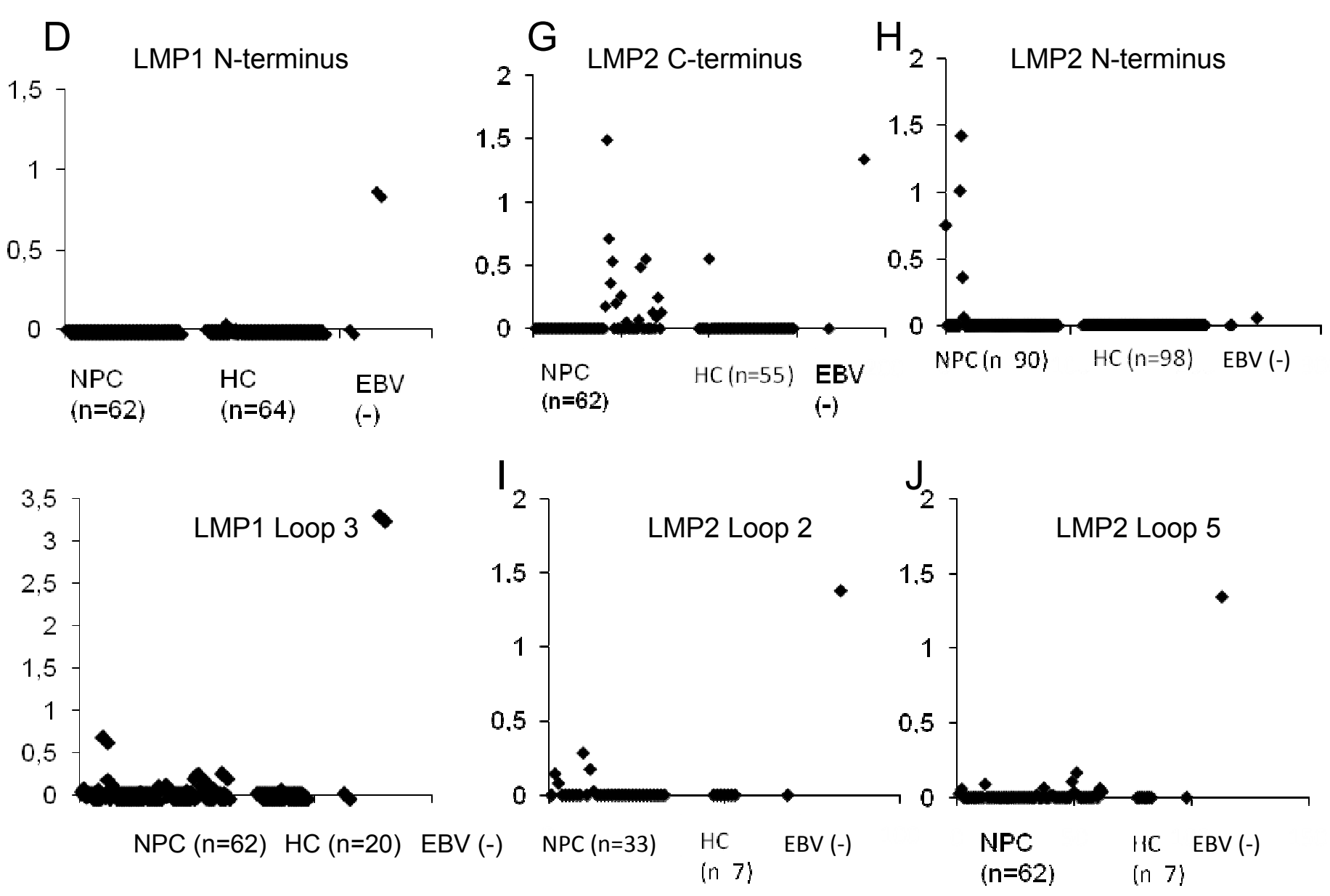

Figure 3

John Wiley \& Sons 

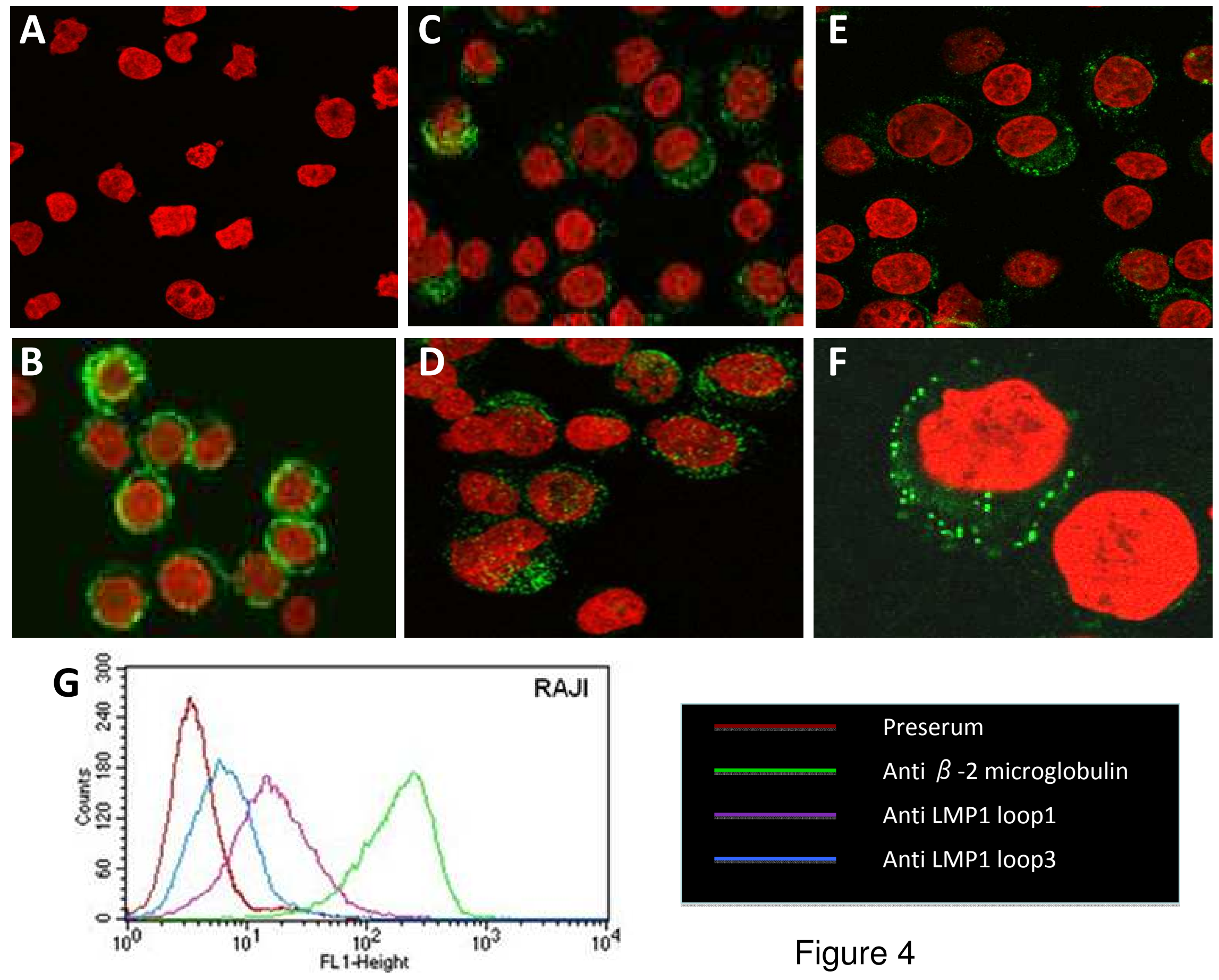

Figure 4 


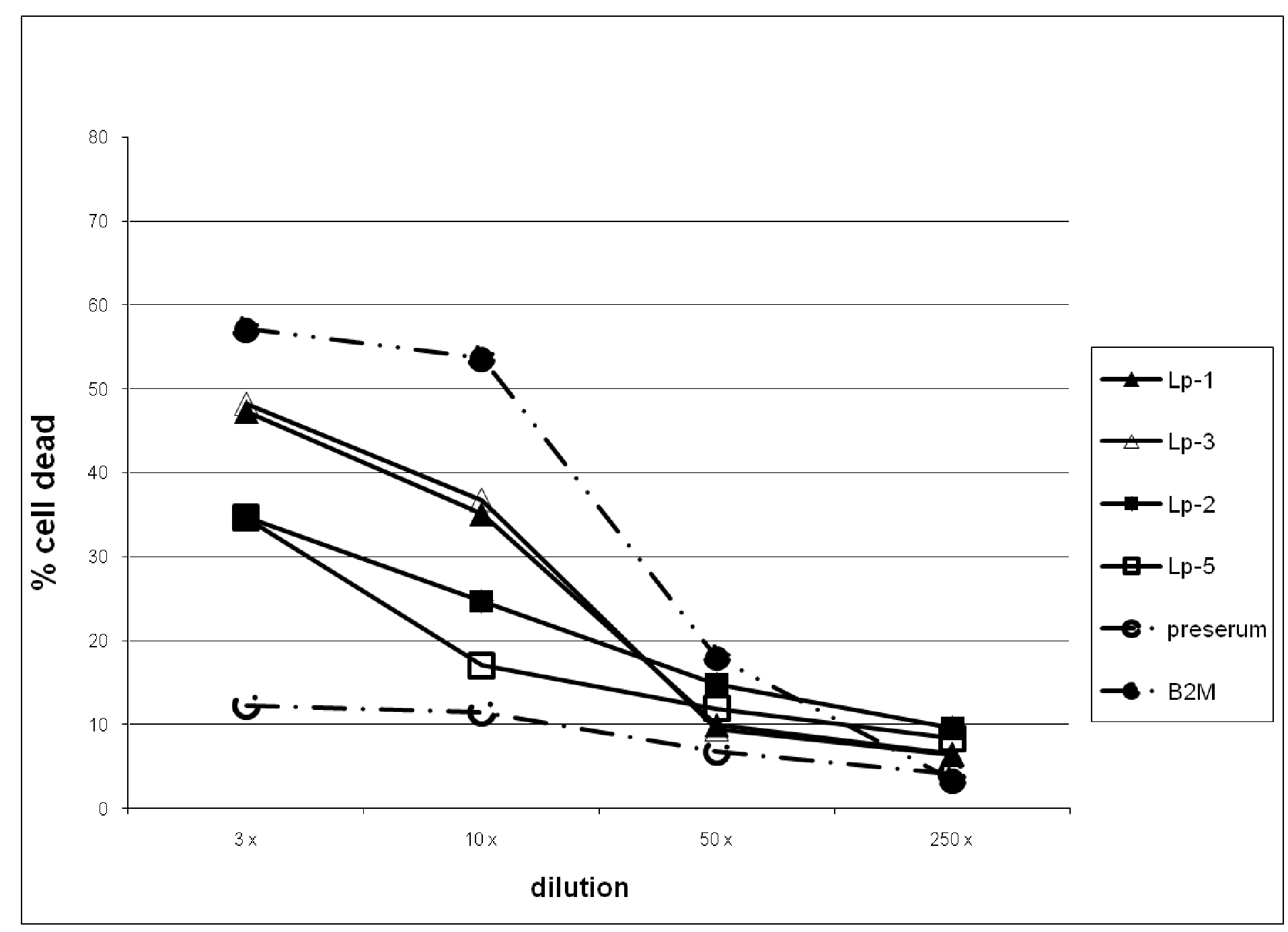

\title{
Figure 5
}

\author{
John Wiley \& Sons
}




\title{
Humoral Immune Responses to Epstein-Barr virus encoded Tumor Associated \\ Proteins and their Putative Extracellular Domains in Nasopharyngeal \\ Carcinoma Patients and Regional Controls
}

\author{
Dewi K. Paramita ${ }^{1}$, Christien Fatmawati ${ }^{2}$, Hedy Juwana ${ }^{3}$, Frank G. van Schaijk ${ }^{3}$, \\ Jajah Fachiroh ${ }^{1}$, Sofia M. Haryana ${ }^{1}$, \\ and Jaap M. Middeldorp ${ }^{3}$
}

1. Molecular Biology Laboratory, Fac. Medicine, Gadjah Mada University, Yogyakarta, Indonesia

2. Fac. Medicine, Gadjah Mada University, Yogyakarta, Indonesia

3. Dept. Pathology, Vrije Universiteit Medical Center, Amsterdam, The Netherlands.

Keywords: Epstein-Barr Virus, nasopharyngeal carcinoma, IgG, IgA, LMP1, LMP2, BARF1

\section{Corresponding Author:}

Prof. dr. J.M. Middeldorp

Dept. Pathology

Vrije Universiteit Medical Center

De Boelelaan 1117

1081 HV Amsterdam

The Netherlands

Tel.: +31-20-4444052

Fax.: +31-20-4442964

E mail: j.middeldorp@vumc.nl 


\section{ABSTRACT}

Epstein-Barr virus latency proteins EBNA1, LMP1, LMP2 and BARF1 are expressed in tumor cells of nasopharyngeal carcinoma (NPC). IgG and IgA antibody responses to these non-self tumor antigens were analysed in NPC patients $(n=125)$ and regional controls $(n=100)$ by three approaches, focusing on the putative LMP1, LMP2 extracellular domains.

Despite abundant $\lg G$ and $\lg A$ antibody responses to lytic antigens and EBNA1, patients had low titer (1:25 - 1:100) lgG to LMP1 (81.2\%), LMP2 (95.6\%) and BARF1 (84.8\%), while immunoblot showed such reactivity in $24.2 \%, 12.5 \%$ and $12.5 \%$ at 1:50 dilution, respectively. Few IgA responses were detected, except for EBNA1. Controls only showed IgG to EBNA1. ELISA using peptides from different domains of LMP1, LMP2 and BARF1 also yielded mostly negative results. When existing, low level IgG to intracellular C-terminus of LMP1 (62.9\%) prevailed.

Rabbit immunisation with peptides representing extracellular (loop) domains yielded loop-specific antibodies serving as positive control. Importantly, these rabbit antibodies stained specifically extracellular domains of LMP1 and LMP2 on viable cells and mediated complement-driven cytolysis. Rabbit anti-LMP1 loop-1 and -3 killed $50.4 \%$ and $59.4 \%$ of $X 50 / 7$ and $35.0 \%$ and $35.9 \%$ of RAJl cells, respectively, and $22 \%$ of both lines were lysed by anti-LMP2 loop- 2 or -5 antibodies.

This demonstrates that (extracellular domains of) EBV-encoded tumor antigens are marginally immunogenic for humoral immune responses. However, peptide specific immunization may generate such antibodies, which can mediate cell killing via complement activation. This opens options for peptide-based tumor vaccination in patients carrying EBV latency-II type tumors such as nasopharyngeal carcinoma. 


\section{INTRODUCTION}

Epstein-Barr virus (EBV) is a human $\gamma$-herpesvirus, that infects more than $90 \%$ of the world population, and is associated with a spectrum of diseases, including infectious mononucleosis (IM) [Henle et al., 1974], Burkitt's lymphoma (BL) [Epstein et al., 1964], Hodgkin's disease [Kapatai and Murray, 2007; Wu et al., 1990], extranodal T/NK cell lymphoma [De Bruin et al., 1993; van Gorp et al., 1996], immunoblastic B-cell lymphomas in immunocompromised individuals [Snow and Martinez, 2007], gastric carcinoma [van Beek et al., 2004] and nasopharyngeal carcinoma [zur Hausen et al., 1970].

EBV persists for life in its human host after the primary infection and is well controlled by the host's immune system. Life-long immunosurveillance is reflected by the persistence of antiviral antibodies and virus reactive (cytotoxic) T cells [Rickinson and Kieff, 2007]. Different sets of proteins expressed during EBV's lytic and latent life cycle induce qualitatively and quantitatively different immune responses [Fachiroh et al., 2004,2006; Hislop et al., 2007]. Similar to other herpes viruses, EBV reactivation can occur in patients with immune defects or immune suppression reflected by aberrant $\mathrm{lgG} / \mathrm{M} / \mathrm{A}$ antibody responses [Meij et al., 1999]. Importantly, EBV may cause a number of malignancies of lymphoid and epithelial origin in both immunosuppressed and immunocompetent individuals, which are also reflected by aberrant antibody responses to EBV.

In the neoplastic cells of these malignancies, several EBV latent gene products are expressed corresponding to the latency type. Nasopharyngeal carcinoma is one of the latency type II tumors and is characterized by expression of EBNA1, LMP1, LMP-2A/ -2B proteins [Brooks et al., 1992; Heussinger et al., 2004; Khabir et al., 2005] with co-expression of the epithelial oncogene BARF1 [Brink et al., 1998; Decaussin et al., 2000; Seto et al., 2005]. In view of potential immunogenicity of virus-encoded "nonself" proteins, it is surprising that LMP1, LMP2 expressing tumors occur in immunocompetent individuals, who are considered to have the capacity of mounting an effective immune response to these "non-self" proteins.

$\mathrm{CD}^{+} \mathrm{T}$ cell responses to EBV latent antigens are skewed towards immunodominant epitopes derived from the EBNA3A, 3B, and $3 \mathrm{C}$ protein family. Accompanying subdominant responses map to additional epitopes from the same EBNA3 family or from LMP2, and much less often to epitopes from EBNA2, EBNALP, or LMP1 [Hislop et al., 2007; Khanna et al., 1992; Murray et al., 1992]. Only 
limited data are available for T cell responses to BARF1 [Martorelli et al., 2008]. Early work on EBNA1 as CD8 ${ }^{+} \mathrm{T}$ cell target showed that the internal 250 amino acid glycine-alanine repeat (GAr) protects the endogenously expressed EBNA1 from $\mathrm{CD}^{+} \mathrm{T}$ recognition [Levitskaya et al., 1995], as consequence from GAr-mediated interference with proteasomal degradation [Dantuma et al., 2002]. EBV has multiple evasion strategies in establishing and maintaining latency in the face of a CD8 ${ }^{+} T$ cell response by switching-off antigen expression in those cells constituting the latent reservoir [Thorley-Lawson, 2001], by inducing T-cell anergy [Dukers et al., 2000] or Treg's [Marshall et al., 2003] or by active interference with antigen processing and presentation during lytic replication [Wiertz et al., 2007; Zuo et al., 2008]. In addition to the EBV-driven immune evasion, nasopharyngeal carcinoma cells can release HLA-class II positive exosomes containing galectin 9, which can trigger apoptosis of mature Th1 cells [Keryer-Bibens et al., 2006; Klibi et al., 2009].

EBNA1 is well recognized as a major target for humoral immune responses. However, only few studies addressed the role of LMP1 and LMP2 proteins as targets for humoral immune responses in detail. Antibody reactivity to LMP1 has been described in different EBV-related patient populations, including nasopharyngeal carcinoma, Hodgkin Disease, mononucleosis, and Burkitt Lymphoma patients, using different techniques, such as ELISA, immunoblot, and migration inhibition assays [Chen et al., 1992; Lennette et al., 1995; Meij et al., 1999; Meij et al., 2002; Modrow and Wolf, 1986; Rowe et al., 1988; Sulitzeanu et al., 1988]. Previous studies indicated that LMP1 is a protein with a low immunogenicity for the humoral immune response in humans. In nasopharyngeal carcinoma only $7.5 \%(3 / 40)$ patients had low serum levels of antibodies directed to LMP1, whereas antibodies to LMP2A/2B were detected at low titer in about $40-60 \%$ of nasopharyngeal carcinoma sera from different ethnicity [Lennette et al., 1995; Meij et al., 1999]. Structurally, LMP1 and LMP2A/B are suggested to protrude from the cell surface via several conserved small loop domains connecting the transmembrane helices [Modrow and Wolf, 1986]. However these loop-domains have not been studied as target for humoral immune response to date. Importantly, such anti-loop antibodies may have potentially important function in targeting complement and/or FcR-bearing killer cells to LMP1, 2 expressing tumor cells. A prior study of antibody to BARF1 in sera with EBVassociated diseases including nasopharyngeal carcinoma suggested that the BARF1 protein may serve as target on EBV-infected cells for antibody dependent cytotoxicity [Tanner et al., 1997]. However, this study has not been confirmed and recent data indicate that BARF1 is rapidly and completely secreted from the EBV positive cells, 
making it a disputable target for antibody dependent cytotoxicity [de Turenne-Tessier et al., 2005; Seto et al., 2005].

In this study, antibody responses to EBV-tumor associated antigens LMP1, LMP2 and BARF1 in nasopharyngeal carcinoma patients were evaluated in details compared to healthy EBV carriers. Specific antibodies to the putative LMP1 and LMP2 extracellular loop domains were further developed and evaluated whether such antibodies can mediate complement killing of the LMP1 and LMP2 expressed cell lines, e.g. RAJI and X50/7. The results may provide a basis for understanding EBV tumor immune escape and indicate options for a novel approach to target extracellular domains of LMP1 and LMP2 expressing tumor cells. 


\section{MATERIAL AND METHODS}

\section{Sera from nasopharyngeal carcinoma patients and Healthy EBV Carriers.}

Serum panels from histologically confirmed nasopharyngeal carcinoma patients (overall $n=125$ ) were collected from department of Ear, Nose and Throat (ENT), Dr. Sardjito General Hospital, Yogyakarta. Nasopharyngeal carcinoma sera were taken on the first visit of patients to the clinic, prior to treatment. Nasopharyngeal carcinoma staging was done by ENT examination and CT-scan and classified according to the 1996 criteria established by UICC (Union International Cancer Control). Sera from healthy EBV carriers (overall $n=100$ ) were obtained from the local red-cross blood bank. All sera were extensively analysed for reactivity to multiple EBV-encoded lytic cycle proteins in prior studies [Fachiroh et al., 2004, 2006; Paramita et al., 2007, 2008]. Nasopharyngeal carcinoma tissues from available formalin fixed paraffin embedded nasopharyngeal carcinoma tumor biopsies were examined the EBV status by EBER in situ staining (DAKO, PNA) and analysed the expression of LMP1 using S12 or OT21C moAbs base immunohistochemistry [Meij et al., 2002].

Cell culture. The EBV positive RAJI Burkitt Lymphoma cell line, the in vitro EBV transformed B cell line X50/7, BJAB-LMP1 (kind gift of M. Rowe) and Daudi-LMP1 (kind gift of $\mathrm{P}$ Busson) were cultured in RPMI-1640 medium comprising 25mM Hepes and glutamin (Sigma, St.Louis, USA), 10\% fetal calf serum (FCS, Hyclone, EttenLeur, The Netherlands), $100 \mathrm{IU} / \mathrm{ml}$ penicillin and $50 \mu \mathrm{g} / \mathrm{ml}$ streptomycin $(\mathrm{p} / \mathrm{s})$ at $37^{\circ} \mathrm{C}$ in a humidified 5\% CO2 atmosphere. Both cell lines express relatively high levels of LMP1 and LMP2 [Bernasconi et al., 2006; Meij et al., 2000b]. Insect cells were cultured as described below.

The BJAB-LMP1 cell is originally from EBV negative cell line BJAB transfected with LMP1 expression vectors. The LMP1-transfected clones of BJAB were established using a tetracycline-regulated vector system and were maintained in culture medium containing $1.5 \mathrm{mg} / \mathrm{ml} \mathrm{G} 418,0.5 \mathrm{mg} / \mathrm{ml}$ hygromycin $\mathrm{B}$, and $1 \mu \mathrm{g} / \mathrm{ml}$ tetracycline. Tetracycline withdrawal induced LMP1 expression as previously described [Floettmann et al., 1996].

Recombinant proteins. The Baculovirus constructs expressing full-length LMP1, LMP2A, BARF1 and EBNA1 without the GAr domain were made under control of the polyhedrin promoter [Meij et al., 2000a; Meij et al., 2000b]. Sf9 cells were cultured to the log phase $\left(1 \times 10^{6}\right.$ cells $\left./ \mathrm{mL}\right)$ and infected with one of the Baculovirus constructs. 
A high dose of 1-5 PFU/cell was used for recombinant protein production and cells were harvested at 48 hours post infection (pi). For immunofluorescence experiments infection at 1 PFU/cell for 48 hours was used leaving about $50 \%$ uninfected cells in the preparation, which were used as specificity control. Insect cells were cultured in serum-free SF900-II medium at $28^{\circ} \mathrm{C}$.

EBV synthetic peptides. Immunodominant epitopes on EBV proteins were derived by computer prediction techniques, as described by Modrow and Wolf [Modrow and Wolf, 1986], using high scores for hydrophilicity, flexibility, and $\beta$-turn probability. Peptides mimicking different domains of LMP1, LMP2 and BARF1 proteins were synthesized with a peptide synthesizer (433A; Applied Biosystem, Foster City, CA). Peptides representing putative extracellular loop domains of LMP1 and LMP2 were also synthesized as circular peptides by inserting two cysteine residues at the ends forming a S-S bridges upon oxidation [Timmerman et al., 2005]. Most peptides were extended at the $\mathrm{N}$-terminus with additional lysine residues for improving solubility and coupling options. All peptides were purified in reverse phase high performance liquid chromatography (Beckman System Gold, Mijdrecht, The Netherlands). Peptide coupling to carrier proteins KLH or TTd was performed by standard techniques using commercial reagents (Sigma, St.Louis, USA). Peptide denomination and amino acids sequences are listed in table 1.

Monoclonal and polyclonal antibodies. Monoclonal (MoAb) and polyclonal (PoAb) antibodies were obtained by immunization of mice and rabbits with synthetic peptides or purified recombinant EBNA1, LMP1, LMP2 and BARF1 proteins expressed in insect cells. Female Chinchilla rabbits were immunized with either keyhole limpet hemocyanine $(\mathrm{KLH})$ or tetanus toxoid (TTd) conjugated synthetic peptides or isotachophoresis isolated recombinant proteins [Meij et al., 1999]. Before immunization pre-serum of each rabbit was drained from the ear. For primary immunization $1 \mathrm{mg}$ antigen was mixed well with $1 \mathrm{ml}$ Freunds Complete Adjuvant (FCA) and injected subcutaneously and intramuscularly. Each rabbit was coded as $\mathrm{k}$ followed with numbers $(\mathrm{xx})$. Approximately 30 days $(+/-1$ day) after primary immunization $5 \mathrm{ml}$ blood was drawn and coded as $\mathrm{kxx} /-1$. First, second and third immunizations with Freunds incomplete adjuvant (FIA) were given with an interval of approximately 1 month. Booster blood samples $(\mathrm{kxx} /-2,-3,4$, or -5$)$ were taken 10 days after booster injection [Aarbiou \& Middeldorp, unpublished]. Production of monoclonal antibodies to various intracellular domains of LMP1 and LMP2 was described before [Fruehling et al., 1996; Meij et al., 1999; Meij et al., 2000b], MoAbs 
to $\mathrm{N}$ - and $\mathrm{C}$-terminal domains of BARF1 were made in-house by standard procedures [Klarenbeek and Middeldorp, unpublished].

\section{Immunofluorescent staining on fixed recombinant antigen-expressing cells.}

Cytospins were made with Sf9 cells either infected with wild type (wt) baculovirus or recombinant baculovirus. Slides were fixed in cold $\left(-20^{\circ} \mathrm{C}\right)$ acetone and preincubated in PBS containing $2 \%$ fetal calf serum (PBS/2\%FCS) for $10 \mathrm{~min}$. All washings were done three times in PBS/0.05\% Tween-20 (PBSt). Antibody dilutions were made in PBS/2\% FCS and incubated at RT. MoAbs were diluted in $100-1000$ times and human sera were used in a 1:25, 1:50, 1:100 and 1:200 and incubated for $1 \mathrm{~h}$ unless stated otherwise. After washing, the slides were incubated for $30 \mathrm{~min}$ with FITC-labeled rabbit anti-mouse Ig or anti human IgG secondary antibodies (DAKO, Glostrup, Denmark). Finally slides were counterstained for 5 min. with a 1:1 mix of DAPI and Evans blue or 1:500 ToPro3 (Partec, Heerhugowaard, The Netherlands) washed, dipped with mounting fluid Vectashield, sealed with a coverslip and evaluated with a Leica DMRB fluorescence microscope (Leica, Cambridge, England).

SDS-PAGE and western blot analysis. Recombinant proteins were solubilized in standard Laemmli sample and boiled for $5 \mathrm{~min}$. and separated in 10\% acrylamide gels using the Mini Protean II system (BioRad, Hercules, USA) under reducing condition. Polypeptides were transferred from the gel onto $0.2 \mu \mathrm{m}$ nitrocellulose (Schleicher \& Schuell, s'Hertogenbosch, the Netherlands) by Western blotting (MiniTrans blot cells, BioRad). After transfer, nitrocellulose sheets were washed with $\mathrm{H}_{2} \mathrm{O}$ and dried between filter paper and stored at $4^{\circ} \mathrm{C}$ until use. Marker proteins (Bio-Rad Low MW marker) were run on the side to indicate the molecular weight of polypeptides. Non-specific binding sites were saturated with blocking buffer $(5 \%$ horse serum and 5\% non-fat dry milk (Campina, Eindhoven, the Netherlands) in PBS $\mathrm{pH}$ 7.2) followed by incubation with Moab or PoAb at appropriate dilutions or sera at different dilutions made in blocking buffer. After washing with PBSt, specific bound $\lg G$ and $\lg A$ were detected with horseradish-peroxidase (HRP)-conjugated secondary antibody (Dako) in blocking buffer and HRP-activity was visualized by using 4-chloro-1-naphtol [Fachiroh et al., 2004].

Synthetic Peptide ELISA. Standard microtiter plates (Biobasic, Toronto, Canada) were coated overnight at $4^{\circ} \mathrm{C}$ with $135 \mu \mathrm{l}$ of one of the peptides in a concentration of $1 \mu \mathrm{g} / \mathrm{ml}$ in $0.05 \mathrm{M}$ carbonate buffer, $\mathrm{pH}$ 9.6. Excess coating fluid was removed and 
non-specific binding sites were blocked subsequently for $1 \mathrm{~h}$ with 200ul/well of $\mathrm{PBS} / 3 \% \mathrm{BSA}$ at $37^{\circ} \mathrm{C}$. Further incubations were performed for $1 \mathrm{~h}$ at $37^{\circ} \mathrm{C}$ followed by four washes with PBSt. Human sera were diluted 1:50 in ELISA sample buffer (PBSt; $0.1 \%$ Triton-X100, 1\% BSA), followed by washing and incubation with HRPlabeled rabbit anti-human $\lg G(1: 3000)$ and $\lg A(1: 2000)$ (DAKO) diluted in conjugate buffer (PBSt; $0.1 \%(\mathrm{v} / \mathrm{v})$ Triton-X100, 1\% BSA and 2\% normal rabbit serum). Peptide-specific Moab or PoAb were diluted in ELISA sample buffer and detected with rabbit anti-mouse or swine anti-rabbit HRP conjugates (Dako) (both at 1:1000), respectively. HRP activity was detected using 3,3',5,5'-tetramethylbenzidine (TMB) (BioMerieux, Boxtel, The Netherlands) and the reaction was stopped by adding $1 \mathrm{M}$ $\mathrm{H} 2 \mathrm{SO} 4$. The optical density was determined at $450 \mathrm{~nm}$ (Anthos 2001 reader, Anthos Labtec, Wals, Austria).

Membrane immunofluorescence on viable cells. Log-phase grown RAJI, X50/7, Daudi-LMP1, BJAB-LMP1 and BJAB cell suspensions were used and all incubations were performed on ice with pre-cooled solution unless mentioned otherwise. Prior to immunofluorescence, lymphoprep purification was performed to remove dead cells from the suspension. Cells were transferred to FACS tubes at $0.5 \times 10^{6}$ cells $/ 100 \mu \mathrm{L}$ staining buffer [Hank balanced salt solution (HBSS); 0.1\% (w/v) NaN3; 1.0\% (w/v) BSA, fraction V)]. Subsequently, appropriate dilutions of PoAb anti-LMP1 loop-1 and -3 and LMP2 loop-2, and -5 were added and incubated for 20 minutes. Following two washes with staining buffer, fluorescein isothiocyanate-labeled swine anti-rabbit $\lg (1: 100)$ in FACS buffer was added and incubated for 20 minutes. For confocal microscopy cells were washed in HBSS, cyto-centrifuged onto glass slides and counterstained for $5 \mathrm{~min}$. Microscopic analysis was done using a Leica TCS confocal microscope (Leica, Cambridge, England) and results were digitally stored. For FACS analysis, the cells were washed three times with staining buffer and resuspended in $100 \mu \mathrm{L}$ propidium iodide solution. Data acquisition was performed on FACSCalibur flow cytometer (BD Biosciences, Franklin Lakes, $N J$ ). Cell staining with anti- $\beta_{2} \mathrm{M}$ antibody (Dako) served as positive control.

MTT assay. To evaluate the cytolytic capacity of anti-LMP1 and -LMP2 loop-specific antibodies, complement cytotoxicity studies were performed with MTT read-out (Cell Proliferation Kit I, Roche, Mannheim, Germany) using EBV, LMP1, 2 positive RAJI and $\mathrm{X} 50 / 7$ cell lines and appropriate controls. All incubations were performed at $37^{\circ} \mathrm{C}$ and $5 \% \mathrm{CO} 2$. Prior to the experiment, lymphoprep purification was performed to remove dead cells. Cells were placed on a 96 well plate at $10^{4}$ cells $/ 25 \mu \mathrm{l}$ per 
well. Antibody anti-loop-1 and -3 LMP1 and anti-loop-2 and -5 LMP2 (1:3, 1:10, 1:50 and 1:250) were added, followed by the addition of $50 \mu \mathrm{l} 30$ times diluted rabbit complement (Innovative Research, Novi, Michigan, USA) and incubated for 2 hrs. As controls, cells were incubated with rabbit preserum or beta-2 microglobuline. Subsequently $5 \mu \mathrm{l}$ MTT labeling reagent was added. After $4 \mathrm{hrs}, 50 \mu \mathrm{L}$ solubilization reagent was added and after overnight incubation, the optical density was determined at 550-600 nm. Percentage of dead cell was calculated by using the formula below.

\section{Percentage (\%) cell death:}

OD of untreated cells (blank) - OD of treated cells $X 100 \%$

OD of untreated cells (blank)

Declaration on human and animal studies. From all nasopharyngeal carcinoma patients in this study informed consent was obtained on the use of their serum/plasma and tumor samples for research purposes and all procedures were approved by the medical ethical committee of the Sardjito University Hospital, Gadjah Mada University, Indonesia. Sera from healthy controls were obtained from the archives and used with permission as detailed in previous studies (Fachiroh et al., 2006).

All animal experiments were performed under approval of specific animal handling and immunization protocols at Organon Teknika, Boxtel, and VU University medical center, Amsterdam, The Netherlands.

All experiments were conducted in compliance with local laws and institutional guidelines, and are in concordance with ethical standards of the Declaration of Helsinki. 


\section{RESULTS}

Humoral immune responses in nasopharyngeal carcinoma patients and healthy EBV carriers to recombinant EBV-encoded Tumor Associated Protein. In this study, we explore the antibody responses of nasopharyngeal carcinoma patients to individual recombinant proteins LMP1, LMP2 and BARF1. Antibody responses to the individual proteins were analyzed by indirect immunofluorescence and immunoblot techniques. Sf9 insect cells infected with recombinant Baculovirus expressing full-length LMP1, LMP2A and BARF1 were used as antigen (rLMP1, rLMP2A, rBARF1, respectively), mainly as described previously [Meij et al., 1999; Meij et al., 2000a; Meij et al., 2000b]. A low MOI was chosen to leave 40-60\% Sf9 cells uninfected, serving as internal specificity control in each experiment. Recombinant EBNA1 deleted of the GAr (rEBNA1) was used as positive control and all sera and MoAbs were analysed in parallel on Sf9-cells infected with wild type Baculovirus (wtBac). Expression of LMP1, LMP2A, BARF1 and EBNA1 in the infected Sf9 cells was confirmed by staining with specific MoAbs to the individual EBV proteins (Figure 1). Human antibody staining was interpreted with the MoAb staining pattern as reference.

Overall, immunofluorescence results with nasopharyngeal carcinoma sera showed rather low (most 1:25-1:100) lgG reactivity to acetone-fixed rLMP1, rLMP2A and rBARF1 being detectable in $81.2 \%, 95.6 \%$ and $84.8 \%$ of tested sera, respectively, whereas IgG to rEBNA1 was present at higher titers $(>1: 200)$ in $100 \%$ of the sera $(n=32)$ (Figure $1 \mathrm{~J})$. In general, observed background reactivity with uninfected Sf9 cells and Sf9-wtBac was minimal and, when present, wt-Bac staining pattern could be discriminated from EBV antigen-specific staining. In simultaneous immunofluorescence analysis, IgA reactivity to $\mathrm{RLMP1}, \mathrm{LMP} 2 \mathrm{~A}$ and BARF1 was observed at even lower titer (<1:25) and at lower frequency in 40.9\%, 54.5\%, and $59.0 \%$ of nasopharyngeal carcinoma sera, respectively. IgA to rEBNA1 was observed at slightly higher titer (1:100) in $81.8 \%$ of the sera $(n=22)$ (data not shown).

Subsequently, to reveal potential immune responses to possible linear epitopes in fully denatured EBV tumor proteins, a set of nasopharyngeal carcinoma sera $(n=123)$ was tested for $\lg G$ and $\lg A$ reactivity by immunoblot analysis at dilutions of 1:50 using lysates of Sf9 cells expressing either rLMP1, rLMP2A, rBARF1 or rEBNA1. Figure 2A-C show that control MoAbs OT21C, 14B7 and 4A6 recognize clear bands at 63kD (LMP1), 54kD (LMP2a) and 30kD (BARF1). In contrast to 
immunofluorescence, immunoblot analysis revealed very low lgG responses to LMP1, LMP2A and BARF1 indicated by weak intensity of the specific protein band in $24.2 \%, 12.5 \%$ and $12.5 \%$ nasopharyngeal carcinoma patients, respectively. In general EBV-protein specific staining by immunoblot was only detectable using the lowest dilution (1:50), if detectable at all. IgG reactivity to rEBNA1 was observed at $94.9 \%$ of nasopharyngeal carcinoma patients (Figure 2D), and showed similar clear band at $55 \mathrm{kD}$ as revealed by MoAb OT1X (figure not shown). None of nasopharyngeal carcinoma patients had detectable IgA response to the LMP1, LMP2A and BARF1 by immunoblot analysis, but a weak IgA response to EBNA1 was observed at $56.5 \%$ nasopharyngeal carcinoma patients. These data indicated that nasopharyngeal carcinoma patients, who have high-level antibody reactivity to multiple lytic cycle antigens and EBNA1 [Fachiroh et al., 2006; Fachiroh et al., 2004], are largely lacking potent antibody responses to tumor associated membrane antigens LMP1 and LMP2A, as well as BARF1, as examined with intact full length recombinant proteins.

\section{LMP1 expression and antibody reactivity in nasopharyngeal carcinoma cases.} No relation was found between LMP1, LMP2 and BARF1 responses (when present) with TNM stage of the tumor. In cases analyzed for serological responses to LMP1 by immunofluorescence assay $(n=32)$ or immunoblot $(n=125)$, the presence of LMP1 was detected at the tumor level using MoAb base immunohistochemistry. Results are shown in table $3 \mathrm{~A}$ and $3 \mathrm{~B}$. Overall $80 \%$ of the nasopharyngeal carcinoma were found to LMP1 expression using immunohistochemistry. In cases having antibody reactive with LMP1 by immunofluorescence assay has positive correlation with LMP expression on the tumor ( $68.8 \%$ concordance), but by IB has negative correlation (33.6\% concordance) (table 3 ).

Immunofluorescence and immunoblot may detect different epitopes, which is related to the level of denaturation of the antigen used, being minimal in immunofluorescence assay using aceton fixation, and maximal in immunoblot using SDS boiling. Therefore, it was decided to analyse this option in more detail. The functional importance of detecting antibody responses to LMP1 and LMP2 conformational domain will be of particular interest when expressed on the tumor cell surface.

Antibody Responses to defined extracellular peptide-epitopes of and LMP1, LMP2 and BARF1. To more precisely study the epitope specificity in the sera of nasopharyngeal carcinoma patients, defined synthetic peptides representing putative 
extracellular domains of LMP1, LMP2 and BARF1 were created and used as antigen in ELISA. Cytoplasmic peptide epitopes of LMP1 and LMP2 and extracellular domain of BARF1 were selected for having high scores for hydrophilicity, flexibility and $\beta$-turn probability as described before [Meij et al., 1999; Middeldorp and Meloen, 1988; Modrow and Wolf, 1986]. In addition, for LMP1 and LMP2 synthetic peptides were also created representing the extracellular loop 1 and 3 (connecting the $1^{\text {st }}$ to $2^{\text {nd }}$ and $5^{\text {th }}$ to $6^{\text {th }}$ transmembrane helix, respectively) and loop 2 and 5 (connecting the $3^{\text {rd }}$ to $4^{\text {th }}$ and $9^{\text {th }}$ to $10^{\text {th }}$ helix respectively), respectively (Figure $3 \mathrm{~A} \& 3 \mathrm{~B}$ ). Synthesis of cytoplasmic peptide domains of LMP1 have been described previously [Meij et al., 1999]. For LMP1, peptide domain in circular conformation to more closely mimick the in vivo structure was used. Circular peptides were created by oxidation of the sulfide bridge in peptides OTP 405 and OTP 407 (Table 1) [Timmerman et al., 2005]. These peptides were used as antigens in indirect ELISA. Epitope-specific antibodies were generated by rabbit immunization using carrier proteins conjugated to the peptides. These newly developed antibodies were used as positive control in the ELISA (Figure 3). All human sera used were strongly responsive to VCA-p18 and EBNA1 synthetic peptides as described before [Fachiroh et al., 2006].

Analysis of LMP1, 2 and BARF1 peptide-epitope specific antibody response by ELISA did not show major differences between nasopharyngeal carcinoma patients and healthy EBV carriers. When detectable, positive responses were marginal in most cases and the most significant response (62.9\% positive) in nasopharyngeal carcinoma patients is confined to IgG against the intracellular C-terminus of LMP1 (Figure $3 \mathrm{C}$ ). Overall analysis is depicted in table 2. Table 2A shows the number of donors and patients having IgG responses to the individual peptides of tumorassociated EBV proteins. IgG responses to LMP2 in healthy EBV carriers were lower compared to responses to LMP1 and BARF1. There was no difference in LMP1 loop-peptide responses when using circular (created by S-S bridge oxidation) or linear peptides (data not shown). None of healthy EBV carriers had IgG responses to LMP2 loop peptides. Responses to C-terminus and N-terminus LMP2 are found only in $2.0 \%$ and $1.8 \%$ of healthy EBV carriers, respectively. About $5 \%$ of healthy EBV carriers had IgG response to subfragments of LMP1 and BARF1. Table 2B shows the number of nasopharyngeal carcinoma patients and healthy EBV carriers with $\lg A$ responses to peptides of LMP1, LMP2 and BARF1. IgA responses are lower as compared to $\operatorname{lgG}$ reponses, and most of the $\lg A$ responses in nasopharyngeal carcinoma patients can also be addressed the C-terminus of LMP1 (27.4\%). 
Accessibility of LMP1 and LMP2 loop domains on viable EBV transformed cells. LMP1 and LMP2 are transmembrane proteins, with six or twelve membranespanning domains, respectively, connected by intracellular and extracellular loops. The extracellular loop domains are potential targets for functional immune responses, and may mediate killing of EBV transformed cells via complement dependent cytotoxicity or killer cell dependent cytotoxic pathways known as antibody dependent cytotoxicity. To study the accessibility of the extracellular loops of LMP1 and LMP2 on viable cells, evaluation of specific antibody recognition of these proteins expressed on viable RAJI, X50/7, Daudi-LMP1, BJAB-LMP1 and BJAB cell lines was done by FACS analysis and confocal microscopy. All cell lines except BJAB cells were positive for LMP1 and LMP2A mRNA as determined by reverse transcription PCR and by intracellular protein staining. For the latter, permeabilized cells were treated with monoclonal antibodies OT21C and 14B7, recognizing the intracellular epitopes of LMP1 and LMP2A respectively (data not shown). Both LMP1 and LMP2A revealed a heterogeneous intracellular staining pattern between individual cells of a cell population as described before [Lennette et al., 1995; Rowe et al., 1988]. The presence of LMP1 and LMP2A loop domains on the surface of those cell lines were detected by indirect fluorescence and FACS analysis using antiloop specific antibodies for LMP1 loop 1 and 3 and LMP2 loop2 and 5 (Figure 4 AG). LMP1 clearly expressed on RAJI and X50/7 (5-15\% of the cells), but clearly negative with Namalwa and BJAB. Figure 4 shows a representative fine patch-like staining observed on 15-20\% of RAJl cells for loop1 and 3 LMP1 (Figure 4C,D) and BJAB as negative control (figure $4 \mathrm{~A}$ ). FACS analysis of RAJl cells using similar antibodies confirmed the low-plevel staining in a restricted number of Raji cells (Figure 4G). On cells artificially expressing LMP1 (Daudi-LMP1 and BJAB-LMP1) by vector transfection much higher staining was seen (20-50\%; Figure 4E). Best LMP2 expression was seen for loop2 on X50/7 cells (Figure 4F). Rabbit antibody against $32 \mathrm{M}$ served as positive control and strongly reacted with $>88 \%$ of all cell lines (Figure $4 B$ and $4 G$ ). Staining pattern of individual viable cells was determined by confocal microscopy, revealing a heterogenous staining pattern similar to the cytoplasmic staining patterns, with some cells being negative, and others being positive and showing a patch-wise distribution of LMP1 and LMP2 related epitopes. This is the first demonstration that extracellular LMP1 and LMP2 related loop domains, can potentially function as targets for antibody-based therapy.

Complement lysis by anti-LMP1 and -LMP2 loop-specific antibodies. Since LMP1 and LMP2 are expressed in multiple EBV tumors, including nasopharyngeal 
carcinoma, targeting of the extracellular domains may have therapeutic potential. This study demonstrated that immunization of rabbits using synthetic peptides mimicking the extracellular loop domains of LMP1 and LMP2 could generate specific anti-loop antibodies. This approach might be applicable to humans as well, aiming for therapeutic vaccination. Considering this option, the functional activity of the anti-loop antibodies was evaluated and complement mediated lysis was analysed using RAJI and $X 50 / 7$ cell lines. Figure 5 shows that by $4 \mathrm{hr}$ complement lysis 35\%, 35.3\%, $22.4 \%$ and $22.3 \%$ of RAJl cells and $50.4 \%, 59.4 \%, 22 \%$ and $22.7 \%$ of X50/7 cells were killed by anti-LMP1 loop 1 and 3 and anti-LMP2 loop 2 and loop 5 antibodies respectively, as measured by MTT assay. Killing potential of each antibody clearly was dose dependent as reflected in the decrease with higher dilution. No cell lysis was observed by pre-serum obtained from these rabbits (Figure 5, bottom line) and no lysis was observed with Namalwa or EBV negative Ramos or BJAB cell lines (data not shown), whereas using $\beta 2 \mathrm{M}$ as target closely to $80 \%$ cells were lysed in this assay. These results demonstrate that newly developed anti-loop antibodies can target specifically and functionally extracellular domains of LMP1 and LMP2, which may have important therapeutic implications. 


\section{DISCUSSION}

Individuals with EBV infection develop antiviral immune responses to a wide variety of EBV proteins and epitopes. Monitoring of anti-EBV antibody responses has yielded useful applications for diagnosis in various EBV-associated diseases, such as nasopharyngeal carcinoma. Elevated antibody titers to EBV antigen e.g. early antigens (EA), viral capsid antigens (VCA) and the EBNA1 protein are frequently found in nasopharyngeal carcinoma patients and are relevant as diagnostic and prognostic markers [Cheng et al., 2002; Fachiroh et al., 2006; Fachiroh et al., 2004; Karray et al., 2005; Ng et al., 2005; Paramita et al., 2007]. However most of the EBV antigens used for diagnosis are not expressed in tumor cells, but are derived from sporadic cells entering the lytic stages infection accompanying the malignant process.

Besides EBNA1, which is expressed universally in all EBV tumor cells, latent EBV proteins such as LMP1 and LMP2 are regularly detected in nasopharyngeal carcinoma [Heussinger et al., 2004; Khabir et al., 2005]. This study could detect LMP1 expression about $80 \%$ of the cases analysed $(n=125)$, but we did not have access to the LMP2-reactive antibodies used by Heussinger. In addition, recent studies revealed the expression and secretion of BARF1 protein in nasopharyngeal carcinoma and gastric cancer in absence of lytic gene expression (Seto et al., 2005). Due to the expression of non-self viral proteins in the nasopharyngeal carcinoma tumor cells, the possibility appears that these proteins might become targets of immune response, aiding in protection. Previous studies demonstrated that EBNA1, LMP2A and to a lesser extend LMP1 can elicit virus-specific cellular immunity and are proposed as antigen for immunotherapy [Comoli et al., 2004; Comoli et al., 2005; Hislop et al., 2007; Swanson-Mungerson et al., 2003]. However, information on humoral immune responses to LMP1, LMP2A and BARF1 antibodies is rather limited [Frech et al., 1993; Lennette et al., 1995; Meij et al., 1999; Tanner et al., 1997]. In the present study using immunofluorescence-analysis on acetone-fixed recombinant proteins expressed in insect cells, IgG antibodies to LMP1 and LMP2 were found in a significant number of nasopharyngeal carcinoma patients $(81.2 \%$ and $95.6 \%$, respectively), albeit in low titers, but hardly in controls. This confirms and extends previous studies that used smaller numbers of patients and controls [Frech et al., 1993; Lennette et al., 1995; Meij et al., 1999]. In all samples tested, the LMP1,2 responses were much lower compared to IgG-EBNA1. By using a similar method this study found that $84.8 \%$ nasopharyngeal carcinoma patients have a detectable but 
low titered IgG response to BARF1. Antibody responses against BARF1 protein have been studied before using sera from chronic and acute infectious mononucleosis and nasopharyngeal carcinoma patients [Tanner et al., 1997]. Using transduced RAJI cells they demonstrated significant antibody dependent cytotoxicity reactivity to BARF1-expressing RAJI cells in sera from nasopharyngeal carcinoma patients. However no study has yet confirmed antibody responses to BARF1 to strengthen these findings. In fact, BARF1 seems to be rapidly and completely secreted by BARF1 expressing cells, leaving little protein in or on the cells for detection [de Turenne-Tessier et al., 2005; Seto et al., 2005]. The role of anti-BARF1 immune responses remains to be further established.

Immunoblotting confirmed the low-level antibody responses, being detectable at $24.2 \%, 12.5 \%$, and $12.5 \%$ of nasopharyngeal carcinoma patients for LMP1, LMP2 and BARF1, respectively. The lower response rates compared to immunofluorescence-analysis may be due to the fact that antigens prepared by SDSPAGE may have lost certain conformational epitopes. Again anti-EBNA1 antibodies were clearly detected, confirming the immunodominance of EBNA1. IgA-specific analysis showed similar low responses to LMP1, LMP2A and BARF1, but again clearly detectable responses to EBNA1. This demonstrates a lack of local mucosaspecific responses to the tumor-associated latent EBV membrane antigens, hinting at specific defects in their presentation to the immune system. These observations are clearly in contrast to the responses to the marginally expressed but highly immunogenic lytic antigens, to which abundant $\lg G$ and $\lg A$ antibody responses are detectable in the same nasopharyngeal carcinoma patients [Fachiroh et al., 2006; Fachiroh et al., 2004; Paramita et al., 2007]. Importantly, most (80\%) nasopharyngeal carcinoma cases analysed showed LMP1 expression. This study found a positive correlation between LMP1 expression and Ab-resposes using immunoflyorescence analysis, but a negative correlation when using immunoblot (table 3). This may suggest that conformational epitopes, which are more reactive by immunofluorescence assay may be triggered in LMP1 positive tumor cases, whereas antibodies to linear (denatured) LMP1 are triggered differently (i.e. by cross presentation). The finding in nasopharyngeal carcinoma differs from previous observation in Hodgkin Disease, where LMP1 antibodies were most prevalent in EBV seropositive but tumor negative cases [Meij et al., 2002].

The data from this study using EBV-recombinant proteins showed that nasopharyngeal carcinoma patients only have weak humoral immune responses to 
LMP1, LMP2 and BARF1. However the potential importance of LMP1 and LMP2 as targets for immunotherapy, prompted us to further analyze the presence of antibodies in nasopharyngeal carcinoma patients directed to defined extracellular epitopes of LMP1, LMP2 and BARF1 in the form of synthetic peptides. No such information was available yet, and, in fact, the extracellular accessibility of domains of LMP1 and LMP2 has not been clearly demonstrated before. Therefore we extended our previous studies and explored responses to defined peptide epitopes mimicking these domain [Meij et al., 1999]. In rabbits, polyclonal epitope-specific antibodies were developed directed against distinct domains of LMP1, LMP2 and BARF1. These antibodies, having a high affinity for their epitopes in denaturated as well as in the native conformation on viable cells, were used as positive controls. Using these anti-loop antibody reagents, demonstration of the presence and functional accessibility of extracellular loop domains of LMP1 and LMP2 was done, opening option as targets for therapeutic applications [Middeldorp, 2002]. However, in naturally EBV infected nasopharyngeal carcinoma patients and healthy EBV carriers these LMP1 and LMP2 loop domains seem to evade from immune recognition, as anti-loop antibody responses are mostly negative (Figure 3 I,F,I,J; Table 2). The results of peptide-specific analysis confirm the presence of some antibody responses to the intracellular $\mathrm{C}$ - and N-terminal domains of LMP1 and LMP2, although only at a low levels (Figure 3C,D). Intrinsic properties of LMP1 and LMP2 and their limited expression in the plasma membrane may be responsible for the low immunogenicity. On the other hand, this study shows that LMP1 and LMP2 antibodies specifically directed against the extracellular loop domains can be generated by immunization of rabbits using related peptides and these antibodies can activate the complement system to kill LMP1 and LMP2 expressing cells. X50/7 cells can be killed by complement $(50.4 \%$ and $59.4 \%)$ in higher percentage compared to RAJI cells (35\% and $35.9 \%$ ) most likely reflecting different level of LMP1 and LMP2 expression or differences in loop-accessibility. This requires further analysis but is in line with known LMP1 expression levels in different cell lines [Meij et al., 2000b]. Detection of extracellular domains requires viable cells and low temperature incubation to inhibit aggregation and internalization activity. A heterogeneous staining pattern of small patches of FITC-labeled anti-loop antibodies was demonstrated in the cell membrane. Also individual cells among the cell population showed a clear distribution (Figure 5). This corresponds with the known heterogeneous intracellular expression of LMP1, being abundant in some cells and barely detectable in others in the same culture [Rowe et al., 1988]. The relation between intracellular situated and membrane-associated LMP1 and LMP2 remains 
to be analysed in detail (studies in progress). Conclusion from this study suggests that limited humoral immune responses to EBV-encoded tumor antigens LMP1, LMP2 and BARF1 allow malignant cells to escape from control. Augmentation of immune reactivity to EBV-tumor associated antigens especially LMP1 and LMP2, by active or passive immunization, may be important to the prevention and treatment of nasopharyngeal carcinoma as a member of latency type II tumors. The finding that immunization of rabbits using these peptides can generate highly reactive epitopespecific antibodies opens new prospects for immunotherapy and vaccination of patients suffering from EBV associated tumors [Middeldorp, 2002]. 
Acknowledgement. We thank the nasopharyngeal carcinoma team of Dr. Sardjito Hospital, Faculty of Medicine, Gadjah Mada University, Indonesia for support in collecting patient samples and dr. Bambang Hariwiyanto, (ENT specialist) and dr. Harijadi (pathologist) for providing clinical and pathological data, and Rurry $T$ Oktariza, Ika Dian Fitria, Beni Sulistyono (students) for doing some peptide ELISAs. We also thank the EBV team in Dept. Pathology, VU University Medical Centre, Amsterdam, the Netherlands, for providing facilities and assistance. We thank to $P$. Busson and M. Rowe for the kind gift of Daudi-LMP1 and BJAB-LMP1 cell lines. This research was funded by the Netherlands Cancer Foundation (grant KWF-IN 2000-02, and 2004-17), the European Union (grant Asia-link, Contract no: ASI/B7301/98/679-034), Ministry of Health Republic of Indonesia (Risbin Iptekdok 2006), and LPPM UGM 2007. 


\section{REFERENCES}

Bernasconi M, Berger C, Sigrist JA, Bonanomi A, Sobek J, Niggli FK, Nadal D. 2006. Quantitative profiling of housekeeping and Epstein-Barr virus gene transcription in Burkitt lymphoma cell lines using an oligonucleotide microarray. Virol J 3:43.

Brink AA, Vervoort MB, Middeldorp JM, Meijer CJ, van den Brule AJ. 1998. Nucleic acid sequence-based amplification, a new method for analysis of spliced and unspliced Epstein-Barr virus latent transcripts, and its comparison with reverse transcriptase PCR. J Clin Microbiol 36(11):3164-3169.

Brooks L, Yao QY, Rickinson AB, Young LS. 1992. Epstein-Barr virus latent gene transcription in nasopharyngeal carcinoma cells: coexpression of EBNA1, LMP1, and LMP2 transcripts. J Virol 66(5):2689-2697.

Chen HF, Kevan-Jah S, Suentzenich KO, Grasser FA, Mueller-Lantzsch N. 1992. Expression of the Epstein-Barr virus latent membrane protein (LMP) in insect cells and detection of antibodies in human sera against this protein. Virology 190(1):106-115.

Cheng WM, Chan KH, Chen HL, Luo RX, Ng SP, Luk W, Zheng BJ, Ji MF, Liang JS, Sham JS, Wang DK, Zong YS, Ng MH. 2002. Assessing the risk of nasopharyngeal carcinoma on the basis of EBV antibody spectrum. Int $\mathbf{J}$ Cancer 97(4):489-492.

Comoli P, De Palma R, Siena S, Nocera A, Basso S, Del Galdo F, Schiavo R, Carminati O, Tagliamacco A, Abbate GF, Locatelli F, Maccario R, Pedrazzoli P. 2004. Adoptive transfer of allogeneic Epstein-Barr virus (EBV)-specific cytotoxic $\mathrm{T}$ cells with in vitro antitumor activity boosts LMP2-specific immune response in a patient with EBV-related nasopharyngeal carcinoma. Ann Oncol 15(1):113-117.

Comoli P, Pedrazzoli P, Maccario R, Basso S, Carminati O, Labirio M, Schiavo R, Secondino S, Frasson C, Perotti C, Moroni M, Locatelli F, Siena S. 2005. Cell therapy of stage IV nasopharyngeal carcinoma with autologous Epstein-Barr virus-targeted cytotoxic T lymphocytes. J Clin Oncol 23(35):8942-8949.

Dantuma NP, Sharipo A, Masucci MG. 2002. Avoiding proteasomal processing: the case of EBNA1. Curr Top Microbiol Immunol 269:23-36.

De Bruin PC, Jiwa NM, Van der Valk P, Van Heerde P, Gordijn R, Ossenkoppele GJ, Walboomers JM, Meijer CJ. 1993. Detection of Epstein-Barr virus nucleic acid sequences and protein in nodal T-cell lymphomas: relation between latent membrane protein-1 positivity and clinical course. Histopathology 23(6):509518.

de Turenne-Tessier M, Jolicoeur P, Middeldorp JM, Ooka T. 2005. Expression and analysis of the Epstein-Barr virus BARF1-encoded protein from a tetracycline-regulatable adenovirus system. Virus Res 109(1):9-18.

Decaussin G, Sbih-Lammali F, de Turenne-Tessier M, Bouguermouh A, Ooka T. 2000. Expression of BARF1 gene encoded by Epstein-Barr virus in nasopharyngeal carcinoma biopsies. Cancer Res 60(19):5584-5588.

Dukers DF, Meij P, Vervoort MB, Vos W, Scheper RJ, Meijer CJ, Bloemena E, Middeldorp JM. 2000. Direct immunosuppressive effects of EBV-encoded latent membrane protein 1. J Immunol 165(2):663-670.

Epstein MA, Achong BG, Barr YM. 1964. Virus Particles In Cultured Lymphoblasts From Burkitt's Lymphoma. Lancet 1(7335):702-703. 
Fachiroh J, Paramita DK, Hariwiyanto B, Harijadi A, Dahlia HL, Indrasari SR, Kusumo H, Zeng YS, Schouten T, Mubarika S, Middeldorp JM. 2006. Singleassay combination of Epstein-Barr Virus (EBV) EBNA1- and viral capsid antigen-p18-derived synthetic peptides for measuring anti-EBV immunoglobulin $\mathrm{G}(\mathrm{IgG})$ and $\mathrm{IgA}$ antibody levels in sera from nasopharyngeal carcinoma patients: options for field screening. J Clin Microbiol 44(4):14591467.

Fachiroh J, Schouten T, Hariwiyanto B, Paramita DK, Harijadi A, Haryana SM, Ng MH, Middeldorp JM. 2004. Molecular diversity of Epstein-Barr virus IgG and IgA antibody responses in nasopharyngeal carcinoma: a comparison of Indonesian, Chinese, and European subjects. J Infect Dis 190(1):53-62.

Floettmann JE, Ward K, Rickinson AB, Rowe M. 1996. Cytostatic effect of EpsteinBarr virus latent membrane protein-1 analyzed using tetracycline-regulated expression in B cell lines. Virology 223(1):29-40.

Frech B, Zimber-Strobl U, Yip TT, Lau WH, Mueller-Lantzsch N. 1993. Characterization of the antibody response to the latent infection terminal proteins of Epstein-Barr virus in patients with nasopharyngeal carcinoma. $\mathbf{J}$ Gen Virol 74 ( Pt 5):811-818.

Fruehling S, Lee SK, Herrold R, Frech B, Laux G, Kremmer E, Grasser FA, Longnecker R. 1996. Identification of latent membrane protein 2A (LMP2A) domains essential for the LMP2A dominant-negative effect on B-lymphocyte surface immunoglobulin signal transduction. J Virol 70(9):6216-6226.

Henle W, Henle GE, Horwitz CA. 1974. Epstein-Barr virus specific diagnostic tests in infectious mononucleosis. Hum Pathol 5(5):551-565.

Heussinger N, Buttner M, Ott G, Brachtel E, Pilch BZ, Kremmer E, Niedobitek G. 2004. Expression of the Epstein-Barr virus (EBV)-encoded latent membrane protein 2A (LMP2A) in EBV-associated nasopharyngeal carcinoma. J Pathol 203(2):696-699.

Hislop AD, Taylor GS, Sauce D, Rickinson AB. 2007. Cellular responses to viral infection in humans: lessons from Epstein-Barr virus. Annu Rev Immunol 25:587-617.

Kapatai G, Murray P. 2007. Contribution of the Epstein Barr virus to the molecular pathogenesis of Hodgkin lymphoma. J Clin Pathol 60(12):1342-1349.

Karray H, Ayadi W, Fki L, Hammami A, Daoud J, Drira MM, Frikha M, Jlidi R, Middeldorp JM. 2005. Comparison of three different serological techniques for primary diagnosis and monitoring of nasopharyngeal carcinoma in two age groups from Tunisia. J Med Virol 75(4):593-602.

Keryer-Bibens C, Pioche-Durieu C, Villemant C, Souquere S, Nishi N, Hirashima M, Middeldorp J, Busson P. 2006. Exosomes released by EBV-infected nasopharyngeal carcinoma cells convey the viral latent membrane protein 1 and the immunomodulatory protein galectin 9. BMC Cancer 6:283.

Khabir A, Karray H, Rodriguez S, Rose M, Daoud J, Frikha M, Boudawara T, Middeldorp J, Jlidi R, Busson P. 2005. EBV latent membrane protein 1 abundance correlates with patient age but not with metastatic behavior in north African nasopharyngeal carcinomas. Virol J 2:39.

Khanna R, Burrows SR, Kurilla MG, Jacob CA, Misko IS, Sculley TB, Kieff E, Moss DJ. 1992. Localization of Epstein-Barr virus cytotoxic $\mathrm{T}$ cell epitopes using recombinant vaccinia: implications for vaccine development. J Exp Med 176(1):169-176. 
Klibi J, Niki T, Riedel A, Pioche-Durieu C, Souquere S, Rubinstein E, Le Moulec S, Guigay J, Hirashima M, Guemira F, Adhikary D, Mautner J, Busson P. 2009. Blood diffusion and Th1-suppressive effects of galectin-9-containing exosomes released by Epstein-Barr virus-infected nasopharyngeal carcinoma cells. Blood 113(9):1957-1966.

Lennette ET, Winberg G, Yadav M, Enblad G, Klein G. 1995. Antibodies to LMP2A/2B in EBV-carrying malignancies. Eur J Cancer 31A(11):1875-1878.

Levitskaya J, Coram M, Levitsky V, Imreh S, Steigerwald-Mullen PM, Klein G, Kurilla MG, Masucci MG. 1995. Inhibition of antigen processing by the internal repeat region of the Epstein-Barr virus nuclear antigen-1. Nature 375(6533):685-688.

Marshall NA, Vickers MA, Barker RN. 2003. Regulatory T cells secreting IL-10 dominate the immune response to EBV latent membrane protein 1 . J Immunol 170(12):6183-6189.

Martorelli D, Houali K, Caggiari L, Vaccher E, Barzan L, Franchin G, Gloghini A, Pavan A, Da Ponte A, Tedeschi RM, De Re V, Carbone A, Ooka T, De Paoli P, Dolcetti R. 2008. Spontaneous T cell responses to Epstein-Barr virusencoded BARF1 protein and derived peptides in patients with nasopharyngeal carcinoma: bases for improved immunotherapy. Int J Cancer 123(5):11001107.

Meij P, Vervoort MB, Aarbiou J, van Dissel P, Brink A, Bloemena E, Meijer CJ, Middeldorp JM. 1999. Restricted low-level human antibody responses against Epstein-Barr virus (EBV)-encoded latent membrane protein 1 in a subgroup of patients with EBV-associated diseases. J Infect Dis 179(5):1108-1115.

Meij P, Vervoort MB, Bloemena E, Schouten TE, Schwartz C, Grufferman S, Ambinder RF, Middeldorp JM. 2002. Antibody responses to Epstein-Barr virus-encoded latent membrane protein-1 (LMP1) and expression of LMP1 in juvenile Hodgkin's disease. J Med Virol 68(3):370-377.

Meij P, Vervoort MB, de Gooijer K, Bloemena E, Meijer CJ, Middeldorp JM. 2000a. Bioreactor-scale production and one-step purification of Epstein-Barr nuclear antigen 1 expressed in baculovirus-infected insect cells. Protein Expr Purif 20(2):324-333.

Meij P, Vervoort MB, Meijer CJ, Bloemena E, Middeldorp JM. 2000b. Production monitoring and purification of EBV encoded latent membrane protein 1 expressed and secreted by recombinant baculovirus infected insect cells. J Virol Methods 90(2):193-204.

Middeldorp J; 2002. Method for the identification of extracellular domains of Epstein-Barr virus (EBV) tumor-associated latent membrane proteins and selection of antibody reagents reactive therewith. International patent WO02/060902 A2.

Middeldorp JM, Meloen RH. 1988. Epitope-mapping on the Epstein-Barr virus major capsid protein using systematic synthesis of overlapping oligopeptides. J Virol Methods 21(1-4):147-159.

Modrow S, Wolf H. 1986. Characterization of two related Epstein-Barr virus-encoded membrane proteins that are differentially expressed in Burkitt lymphoma and in vitro-transformed cell lines. Proc Natl Acad Sci U S A 83(15):5703-5707.

Murray RJ, Kurilla MG, Brooks JM, Thomas WA, Rowe M, Kieff E, Rickinson AB. 1992. Identification of target antigens for the human cytotoxic $T$ cell response to Epstein-Barr virus (EBV): implications for the immune control of EBVpositive malignancies. J Exp Med 176(1):157-168. 
Ng WT, Yau TK, Yung RW, Sze WM, Tsang AH, Law AL, Lee AW. 2005. Screening for family members of patients with nasopharyngeal carcinoma. Int J Cancer 113(6):998-1001.

Paramita DK, Fachiroh J, Artama WT, van Benthem E, Haryana SM, Middeldorp JM. 2007. Native early antigen of Epstein-Barr virus, a promising antigen for diagnosis of nasopharyngeal carcinoma. J Med Virol 79(11):1710-1721.

Paramita DK, Fachiroh J, Haryana SM, Middeldorp JM. 2008. Evaluation of commercial EBV RecombLine assay for diagnosis of nasopharyngeal carcinoma. J Clin Virol 42(4):343-352.

Rickinson A, Kieff E. 2007. Epstein-Barr virus. In: Fields Virology. $5^{\text {th }}$ Edition; B, Knipe D, Howley P, editors. Publ. Lippincott, Williams \& Wilkin, Philadelphia: 2656-2700.

Rowe M, Finke J, Szigeti R, Klein G. 1988. Characterization of the serological response in man to the latent membrane protein and the six nuclear antigens encoded by Epstein-Barr virus. J Gen Virol 69 ( Pt 6):1217-1228.

Seto E, Yang L, Middeldorp J, Sheen TS, Chen JY, Fukayama M, Eizuru Y, Ooka T, Takada K. 2005. Epstein-Barr virus (EBV)-encoded BARF1 gene is expressed in nasopharyngeal carcinoma and EBV-associated gastric carcinoma tissues in the absence of lytic gene expression. J Med Virol 76(1):82-88.

Snow AL, Martinez OM. 2007. Epstein-Barr virus: evasive maneuvers in the development of PTLD. Am J Transplant 7(2):271-277.

Sulitzeanu D, Szigeti R, Hatzubai A, Dillner J, Hammarskjold ML, Klein G, Klein E. 1988. Antibodies in human sera against the Epstein-Barr virus encoded latent membrane protein (LMP). Immunol Lett 18(4):301-306.

Swanson-Mungerson M, Ikeda M, Lev L, Longnecker R, Portis T. 2003. Identification of latent membrane protein 2A (LMP2A) specific targets for treatment and eradication of Epstein-Barr virus (EBV)-associated diseases. $\mathrm{J}$ Antimicrob Chemother 52(2):152-154.

Tanner JE, Wei MX, Alfieri C, Ahmad A, Taylor P, Ooka T, Menezes J. 1997. Antibody and antibody-dependent cellular cytotoxicity responses against the BamHI A rightward open-reading frame-1 protein of Epstein-Barr virus (EBV) in EBV-associated disorders. J Infect Dis 175(1):38-46.

Thorley-Lawson DA. 2001. Epstein-Barr virus: exploiting the immune system. Nat Rev Immunol 1(1):75-82.

Timmerman P, Beld J, Puijk WC, Meloen RH. 2005. Rapid and quantitative cyclization of multiple peptide loops onto synthetic scaffolds for structural mimicry of protein surfaces. Chembiochem 6(5):821-824.

van Beek J, zur Hausen A, Klein Kranenbarg E, van de Velde CJ, Middeldorp JM, van den Brule AJ, Meijer CJ, Bloemena E. 2004. EBV-positive gastric adenocarcinomas: a distinct clinicopathologic entity with a low frequency of lymph node involvement. J Clin Oncol 22(4):664-670.

van Gorp J, Brink A, Oudejans JJ, van den Brule AJ, van den Tweel JG, Jiwa NM, de Bruin PC, Meijer CJ. 1996. Expression of Epstein-Barr virus encoded latent genes in nasal T cell lymphomas. J Clin Pathol 49(1):72-76.

Wiertz EJ, Devlin R, Collins HL, Ressing ME. 2007. Herpesvirus interference with major histocompatibility complex class II-restricted T-cell activation. J Virol 81(9):4389-4396.

Wu TC, Mann RB, Charache P, Hayward SD, Staal S, Lambe BC, Ambinder RF. 1990. Detection of EBV gene expression in Reed-Sternberg cells of Hodgkin's disease. Int J Cancer 46(5):801-804. 
Zuo J, Thomas W, van Leeuwen D, Middeldorp JM, Wiertz EJ, Ressing ME, Rowe M. 2008. The DNase of gammaherpesviruses impairs recognition by virusspecific CD8+ $\mathrm{T}$ cells through an additional host shutoff function. $\mathrm{J}$ Virol 82(5):2385-2393.

zur Hausen H, Schulte-Holthausen H, Klein G, Henle W, Henle G, Clifford P, Santesson L. 1970. EBV DNA in biopsies of Burkitt tumours and anaplastic carcinomas of the nasopharynx. Nature 228(5276):1056-1058. 


\section{Legends to the figures:}

\section{Figure 1.}

Antibody detection by indirect immunofluorescence of acetone-fixed Sf9 cells infected with Baculo-EBNA1 (A, B), Baculo-LMP1 (C, D), Baculo- LMP2A (E, F), Baculo-BARF1 (G, H) and WT-baculovirus (I).

Cells were incubated with OT1X (1:200, mouse anti-EBNA1) (A), OT21C (1:100, mouse anti-LMP1) (C), 14B7 (1:100, rat anti-LMP2A) (E), K150-3 (1:100, rabbit antiBARF1) (G), and serum of NPC patients containing antibodies anti-EBNA1, LMP1, LMP2A and BARF1 (B, D, F, H respectively). Sf9-WT-Bac served as negative control incubated with either Mo/PoAbs or NPC serum (I). Similar pattern was observed as Baculo-BARF1 incubated using K150-3, when the cells were incubated with mouse MoAb 4A6 (mouse anti-BARF1). (J) Bar chart shows the summary of antibody responses of NPC sera to Sf9 cells infected with Baculo- EBNA1, -LMP1, -LMP2A and -BARF1 respectively, as detected by indirect immunoflourescence. For an indication of the level of antibody response, NPC sera were examined at various dilutions, as Indicated.

\section{Figure 2.}

Immunoblot analysis of SF9-baculo expressed recombinant proteins stained with monoclonal, mono-reactive polyclonal antibodies and NPC sera.

(A) Baculo-LMP1 strips, (B) Baculo-LMP2A strips, (C) Baculo-BARF1strips, stained with Mo/PoAbs specific to the protein (strip 1 for each immunoblot series) and stained with NPC sera (line 2-end for each series). (A-OT21C) Baculo-LMP1 strip stained with OT21C MoAb showing band on 63kD, (B-14B7) Baculo-LMP2A strip stained with 14B7 PoAb showing band on 54kD, (C-K150-3) Baculo-BARF1 strip stained with K150-3 PoAb showing band on 30kD. (A1 - A23) Baculo-LMP1 strip stained with NPC serum (1:50), (B1-B23) Baculo-LMP2A strip stained with NPC serum (1:50), (C1-C19) Baculo-BARF1 strip stained with NPC serum (1:50). (D) Bar charts summary of antibody responses of NPC sera to Sf9 cells infected with BaculoEBNA1, -LMP1, -LMP2A and -BARF1 using IB. For an indication of the level of antibody response, NPC sera were examined at 1:50 dilutions. 


\section{Figure 3.}

Structural representation of LMP1 and LMP2A molecule in the plasma membrane and IgG responses of NPC patients and healthy EBV carriers to peptide epitopes of LMP1 and LMP2A.

Both proteins contain an intracellular N and C-terminus. (A) LMP1 is characterized by three short extracellular loops connecting the six membrane-spanning segment. (B) LMP2 has 6 short extracellular loops, connecting 12 membrane spanning domains. (A) Anti-C terminus, $-\mathrm{N}$ terminus, -loop-1 and -loop-3 of LMP1 and (B) anti-C terminus, $-\mathrm{N}$ terminus, -loop-2 and -loop-5 of LMP2 specific antibodies were generated by rabbit immunization. Polyclonal antibodies generated from rabbit immunization with the LMP1 peptide showed strong specific reactivity to each epitope as shown at the upper right of each graph as positive control: (C) K49-3 to the C-terminus LMP1, (D) K48-3 to the N-terminus LMP1, (E) K31-3 to the Loop1 and $(\mathrm{F}) \mathrm{K} 56-3$ to the Loop-3. Polyclonal antibodies generated from rabbit immunization with the LMP2A peptides showed strong specific reactivity to each epitope as shown at the upper right of each graph as positive control: (G) K41-3 to C-terminus, (H) K42-3 to N terminus, (I) K47-3 to Loop-2 and (J) K43-3 to Loop-5. NPC: nasopharyngeal carcinoma, HC: Healthy EBV carrier.

\section{Figure 4.}

Accessibility of extracellular loops of LMP1 on viable RAJI and BJAB cells as determined by specific anti-loop antibodies.

(A) In all experiments EBV negative BJAB cells produced a complete negative membrane staining with the LMP1 and LMP2 loop-specific sera. (B) As positive control, RAJI and BJAB cells showed more than $88 \%$ positive staining using anti- $\beta$ 2microglobulin. (C, D) A fine patch-like staining was observed on the surface of RAJI cells with anti-LMP1 loop-1 and loop-3 specific antisera (C, D respectively). Note that some cells in the culture were negative for Loop-1-3 expression, which were generally having small nuclei, representing non-cycling cells. (E) Anti-LMP1 loop-1, 3 specific antisera produced a similar, but more abundant patch-like staining on stably transfected BJAB cells induced for LMP1 expression from a teracyclin regulated promoter during 24 hours, similar as observed with LMP1 transfected Daudi cells (data not shown). (F) Antisera to LMP2 loop-2 and -5, produced a similar patched staining pattern on X50-7 cells, with somewhat larger patches than observed for LMP1. (G) Flow cytometry histogram comparing the levels of accessibility of anti loops LMP1 on Raji cells. Cells were gated for viability by 7-AAD exclusion. Staining was obtained with the indicated rabbit anti-LMP1 loop-1 (purple line), rabbit anti- 
LMP1 loop-3 (blue line) and using rabbit anti-b2M as positive control (green line). Background staining with rabbit pre-serum shows low signal as indicated by the red line, which is similar to anti-loop antiserum on control BJAB cells (data not shown).

\section{Figure 5.}

Complement mediated cell lysis. RAJl cells were incubated with a dilution series of anti-loop antibodies (3x, 10x, 50x and 250x) and 30 times diluted complement solution. Percentage cell death is plotted against antibody dose. In $3 x$ dilution of antiloop antibodies, approximately 49\% RAJl cells were killed by anti-loop-1 and -3 LMP1 and $35 \%$ by anti-loop-2 and loop-5 LMP2A. Similar results or even higher killed-cells were obtained in other EBV carrying LCL lines but not in Namalwa, an EBV positive cell lines with LMP1 and LMP2 negative. Anti-B2M antibody was taken as a positive control, and used at larger dilution (1:5000) and therefore is not reaching $>80 \%$ lysis. Preserum was used as negative control and to distinguish with specific binding of specific antibodies. 
Table 1.

Amino acid sequence of LMP1, LMP2 and BARF1-derived synthetic peptides

\begin{tabular}{|c|c|c|}
\hline Peptide & Amino acid sequence & $\begin{array}{l}\text { AA } \\
\text { position }\end{array}$ \\
\hline \multicolumn{3}{|l|}{ LMP1: } \\
\hline OTP 415 (Loop1) & H-KKKCYIVMSDWTGGALLVLYC-NH ${ }_{2}$ & $41-56$ \\
\hline OTP 417 (Loop3) & H-KKKCALYLQQNWWTLLVDLLC-NH ${ }_{2}$ & $157-172$ \\
\hline $\begin{array}{l}\text { OTP } 81(\mathrm{~N}- \\
\text { term/LMP1-A) }\end{array}$ & H-MEHDLERGPPGPRRPPRGPPLSS-OH & $1-23$ \\
\hline $\begin{array}{l}\text { OTP } 75(\mathrm{C}- \\
\text { term/LMP1-D) }\end{array}$ & H-GSSGSGGDDDDPHGPVQLSYYD-OH & $365-386$ \\
\hline \multicolumn{3}{|l|}{ LMP2: } \\
\hline OTP 307 (Loop2) & H-AICLTWRIEDPPFNSLLFAL-OH & $183-202$ \\
\hline OTP 308 (Loop5) & H-GSILQTNFKSLSSTEFIPNLFGM-OH & $363-385$ \\
\hline OTP 309 (C-term) & H-RCCRYCCYYCLTLESEERPPTPYRNTV-OH & $461-497$ \\
\hline OTP 310 (N-term) & H-SGSSGNTPTPPNDEERESNEEPPPPYEDPY-OH & $35-64$ \\
\hline BARF1: & 20 & \\
\hline OTP 539 (C term) & $\begin{array}{l}\text { H-LGPEIEVSWFKLGPGEEQVLIGRMHHDVIFIEWP- } \\
\text { FRGFFD-OH }\end{array}$ & $40-80$ \\
\hline OTP $541(\mathrm{~N}$ term $)$ & $\begin{array}{l}\text { H-DLSLPKPWHLPVTCVGKNDKEEAHGVYVSGYL-SQ- } \\
\text { OH }\end{array}$ & $187-231$ \\
\hline
\end{tabular}

Table 2A.

Positive IgG responses (\%) in NPC and healthy EBV carriers to LMP1, LMP2 and BARF1 peptides.

\begin{tabular}{|l|c|c|c|c|c|c|c|c|c|c|}
\hline & \multicolumn{3}{|c|}{ LMP1 (\%) } & \multicolumn{4}{c|}{ LMP2A (\%) } & \multicolumn{2}{c|}{ BARF1 (\%) } \\
\hline & Loop1 & Loop3 & $\begin{array}{c}\text { C- } \\
\text { term }\end{array}$ & $\begin{array}{c}\text { N- } \\
\text { term }\end{array}$ & Loop2 & Loop5 & $\begin{array}{c}\text { C- } \\
\text { term }\end{array}$ & $\begin{array}{c}\text { N- } \\
\text { term }\end{array}$ & $\begin{array}{c}\text { C- } \\
\text { term }\end{array}$ & $\begin{array}{c}\text { N- } \\
\text { term }\end{array}$ \\
\hline HC & 5.0 & 5.0 & 5.0 & 6.3 & 0 & 0 & 2.0 & 1.8 & 5.0 & 5.0 \\
\hline NPC & 14.5 & 38.7 & 62.9 & 11.3 & 21.2 & 24.2 & 8.9 & 21.9 & 3.2 & 21 \\
\hline
\end{tabular}

Table 2B.

Positive IgA responses (\%) of NPC and healthy EBV carriers to LMP1, LMP2 and BARF1 peptides.

\begin{tabular}{|l|c|c|c|c|c|c|c|c|c|c|}
\hline & \multicolumn{3}{|c|}{ LMP1 (\%) } & \multicolumn{3}{c|}{ LMP2A (\%) } & \multicolumn{2}{c|}{ BARF1 (\%) } \\
\hline & Loop1 & Loop3 & $\begin{array}{c}\text { C- } \\
\text { term }\end{array}$ & $\begin{array}{c}\text { N- } \\
\text { term }\end{array}$ & Loop2 & Loop5 & $\begin{array}{c}\text { C- } \\
\text { term }\end{array}$ & $\begin{array}{c}\text { N- } \\
\text { term }\end{array}$ & $\begin{array}{c}\text { C- } \\
\text { term }\end{array}$ & $\begin{array}{c}\text { N- } \\
\text { term }\end{array}$ \\
\hline HC & 5.0 & 5.0 & 10.0 & 3.0 & 0 & 0 & 1.0 & 5.5 & 5.0 & 5.0 \\
\hline NPC & 1.6 & 0 & 27.4 & 3.2 & 18.2 & 3.2 & 20.0 & 17.8 & 6.5 & 11.3 \\
\hline
\end{tabular}


Table 3A.

Correlation between LMP1 expression using IHC and IgG reactivity to LMP1 recombinant proteins by IFA in NPC patients

\begin{tabular}{|c|l|c|c|c|}
\cline { 3 - 4 } \multicolumn{2}{c|}{} & \multicolumn{2}{c|}{ IHC } & \multirow{2}{*}{ Concordance } \\
\cline { 3 - 4 } \multirow{2}{*}{ IFA } & + & 21 & - & \\
\cline { 2 - 4 } & - & 5 & 1 & $68.8 \%$ \\
\hline
\end{tabular}

Table 3B.

Correlation between LMP1 expression using IHC and IgG reactivity to $L M P 1$ recombinant proteins by IB in NPC patients

\begin{tabular}{|c|c|c|c|c|}
\hline & \multicolumn{2}{|c|}{ IHC } & \multirow{2}{*}{ Concordance } \\
\hline & & + & - & \\
\hline \multirow{2}{*}{ IB } & + & 27 & 5 & \multirow{2}{*}{$33.6 \%$} \\
\hline & - & 78 & 15 & \\
\hline
\end{tabular}

